\title{
Metal-Based Complexes as Pharmaceuticals for Molecular Imaging of the Liver
}

\author{
Julia Greiser ${ }^{1}$, Wolfgang Weigand ${ }^{2, *(\mathbb{D})}$ and Martin Freesmeyer ${ }^{1, *}$ \\ 1 University Hospital Jena, Clinic of Nuclear Medicine, Am Klinikum 1, 07747 Jena, Germany; \\ julia.greiser@med.uni-jena.de \\ 2 Institute for Inorganic and Analytical Chemistry, Friedrich Schiller University, Humboldtstrasse 8, \\ 07743 Jena, Germany \\ * Correspondence: wolfgang.weigand@uni-jena.de (W.W.); martin.freesmeyer@med.uni-jena.de (M.F.); \\ Tel.: +49-3641-9329801 (M.F.)
}

Received: 21 August 2019; Accepted: 11 September 2019; Published: 16 September 2019

\begin{abstract}
This article reviews the use of metal complexes as contrast agents (CA) and radiopharmaceuticals for the anatomical and functional imaging of the liver. The main focus was on two established imaging modalities: magnetic resonance imaging (MRI) and nuclear medicine, the latter including scintigraphy and positron emission tomography (PET). The review provides an overview on approved pharmaceuticals like Gd-based CA and ${ }^{99 \mathrm{~m}} \mathrm{Tc}$-based radiometal complexes, and also on novel agents such as ${ }^{68} \mathrm{Ga}$-based PET tracers. Metal complexes are presented by their imaging modality, with subsections focusing on their structure and mode of action. Uptake mechanisms, metabolism, and specificity are presented, in context with advantages and limitations of the diagnostic application and taking into account the respective imaging technique.
\end{abstract}

Keywords: liver; molecular imaging; metals; MRI; SPECT; PET; radiopharmaceuticals; contrast agents; metal complexes; diagnostics

\section{Introduction}

Liver imaging is an essential diagnostic tool which, in addition to biopsy and laboratory tests, provides information on the spatial distribution of liver function and allows the detection and differentiation of benign and malignant liver lesions [1]. Next to the kidneys, the liver is the major organ responsible for clearing the blood by metabolizing and excreting substances and toxins. In addition, the liver acts as the largest gland in the human body, producing bile, cholesterol, and vital proteins, and also acting as hormone regulator [2]. The enormous relevance and scope of liver imaging become immediately clear considering that liver cancers, particularly hepatocellular carcinoma (HCC), represent one of the three most frequent causes of cancer-related deaths worldwide [3], and that other chronic liver diseases, such as cirrhosis, fibrosis, and hepatitis, affect approximately 29 million patients in the European Union alone [4]. The prevalence of these disorders emphasizes not only the diagnostic relevance of liver imaging, but also its role for therapy monitoring purposes, e.g., following chemotherapy or transplantation.

In clinical routine, liver imaging is performed using a wide spectrum of tools including ultrasound, fluorescence imaging, and molecular methods such as magnetic resonance imaging (MRI), single photon emission computed tomography (SPECT), and positron emission tomography (PET). Particularly, the latter three methods employ metal complexes such as contrast agents (CA) or radiotracers, visualizing the interaction between the pharmaceutical agent and a biological target within the liver, e.g., hepatocytes, hepatic transporters, or vascular system [5,6]. The liver parenchyma consists mainly of hepatocytes, responsible for producing proteins and bile, and Kupffer cells, i.e., resident macrophages 
which are part of the reticuloendothelial system (RES) and contribute to immunity; therefore, specific hepatic uptake of a metal complex can be basically achieved by targeting one of these two cell types.

Metals constitute the largest part of the periodic table of elements, most of them existing in several oxidation states and various isotopes of which many are radioactive. The design of ligands for metal coordination is limited only by imagination, providing access to a rich field of metal-based pharmaceuticals designed for any specific diagnostic problem. The aim of this review was to systematically present the most relevant metal complexes used for liver imaging, relating their field of application to structural considerations, liver uptake, metabolism, and imaging characteristics, as well as to highlight recent developments in the respective fields.

\section{Metal Complexes in Liver Specific MRI}

\subsection{MRI Principle and Relevant Metals}

Magnetic resonance imaging is based on the application of a strong magnetic field around the body, causing hydrogen protons present within the tissues to align due to the fact of their intrinsic magnetic moment. Radiofrequency pulses applied during the measurement cause excitation of the protons. Once the pulse is turned off, the protons relax back to their initial energy state, thereby releasing energy and causing a change in the net magnetization, which can be detected and used for imaging purposes. Signal intensity depends on the relaxation time and proton density; hence, MRI provides images that contain anatomical information based on tissue properties. Elements like carbon $\left({ }^{13} \mathrm{C}\right)$ and phosphor $\left({ }^{31} \mathrm{P}\right)$ also produce MR signals, but hydrogen remains the element of choice due to the fact of its abundance in the body [7].

Due to the dipolar interactions between unpaired electrons and the hydrogen nucleus, CA based on paramagnetic metals shortens the relaxation times of protons, thereby increasing signal intensity [8-11]. While transition metal ions like $\mathrm{Mn}$ (II) and Fe(III) can also be used for MRI, complexes of lanthanide gadolinium $(\mathrm{Gd}(\mathrm{III}))$ are the most established CA due to the high number of unpaired electrons resulting in a large magnetic moment and high relaxation efficiency [12,13]. Common CA like Gd-diethylenetriamine pentaacetic acid (DTPA)) are considered extracellular CA because they distribute through the vascular system and enhance tissue contrast depending on the perfusion characteristics and relaxation behavior of the chemical environment [14].

The main benefits of MRI consist in the provision of high-contrast images of organs and tissues-particularly soft-tissue structures-with a resolution in the sub-millimeter range [5,6,15], and the obvious advantage of no radiation exposure. However, patients suffering from claustrophobia and — due to the presence of a strong magnetic field—patients bearing metal implants (e.g., pacemakers) often cannot undergo an MRI examination. Furthermore, renal insufficiency is a common contraindication for the use of CA [16].

\subsection{Gd-Based Liver Specific CA Gd-EOB-DTPA and Gd-BOPTA}

Although liver MRI can be performed using unspecific extracellular CA or even without any CA [11,14], contrast-enhanced MRI remains the cornerstone for liver lesion characterization, with liver-specific CA additionally providing relevant functional information $[9,11,17]$. Since extracellular CA do not enter the hepatocytes, the information gained is limited to a short imaging window in the first minutes, based on different vascularity of tumoral lesion and normal liver tissue [18]. Following bolus injection of an extracellular CA, its distribution is higher in tumoral tissues due to the fact of their over-proportional arterial blood supply [14,19]. In contrast, following bolus injection of a liver-specific CA, the imaging quality is based on two different aspects: the early arterial and venous phase provides information on the lesion vascularity (similar to the information provided by extracellular CA), while the so-called late phase is characterized by hepatocellular-specific uptake of the CA and its subsequent hepatobiliary excretion (Figure 1) $[9,14,17,18]$. Thus, information on hepatocyte presence and liver function is gained in parallel due to the contrast between the healthy 
hepatocytes (which take up the CA) and the tumoral tissue, which does not take up the CA [17]. An additional benefit of using liver-specific CA is the possibility of imaging the gallbladder and the biliary tree [11,14]. In general, a major advantage is that images can be acquired in three-dimensional datasets with high temporal and spatial resolution $[9,11]$.

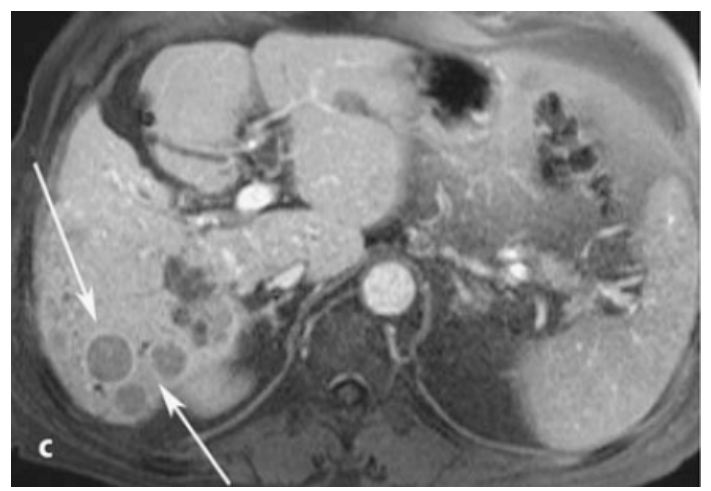

Figure 1. Late phase MRI of the liver obtained after bolus injection of Gd-EOB-DTPA (gadoxetate), showing the presence of hepatocellular carcinoma lesions (arrows). Reprinted with permission from Reference [14].

Thus far, Gd-EOB-DTPA (gadoxetate) is the gold standard for liver-specific MRI. Approximately $50 \%$ of the administered dose is taken up by hepatocytes and subsequently excreted into the bile via multidrug resistance protein (MRP) 2 [1,20], while the remainder is excreted renally [11,21]. In normally functioning hepatocytes, the uptake is mediated through the organic anion transporters (OATP) OATP1B1 and OATP1B3 as well as via $\mathrm{Na}^{+} /$taurocholate co-transporting polypeptide (NTCP), while hepatic lesions usually exhibit a reduced CA uptake [1,11,21,22].

Gd-BOPTA (gadobenate-dimeglumine) [14] exhibits less hepatic uptake (5\%) than Gd-EOB-DTPA and is therefore inferior in terms of late-phase parenchymal enhancement $[9,11]$. However, Gd-BOPTA exhibits a higher enhancement of hepatic vascular structures [11] due to the fact of its increased relaxation enhancement in the presence of albumin $[10,23,24]$. The maximum parenchymal enhancement is delayed for Gd-BOPTA (0.5-2 h post injection (p.i.)) compared to Gd-EOB-DTPA (20 min p.i.), meaning that imaging with Gd-BOPTA requires two scans in order to obtain both anatomical and functional information, while imaging with Gd-EOB-DTPA gathers both pieces of information in a single acquisition setting $[11,18,25]$. The agent Gd-BOPTA is mainly used for liver lesion identification and characterization in early and late phase [19,26], but can also be used for cholangiography [27].

Although the hepatic specificity of Gd-EOB-DTPA and Gd-BOPTA is markedly different, the only structural difference lies in a p-ethoxybenzyl group in EOB-DTPA in contrast to a benzyloxyethyl group in BOPTA (Figure 2), allowing the assumption that alkoxybenzylic structures address the liver more efficiently than non-substituted aromatic rings. In the blood, in contrast, Gd-EOB-DTPA and Gd-BOPTA exhibit a similar serum protein binding (approximately 10\%) due to the presence of their aromatic rings [28]. 


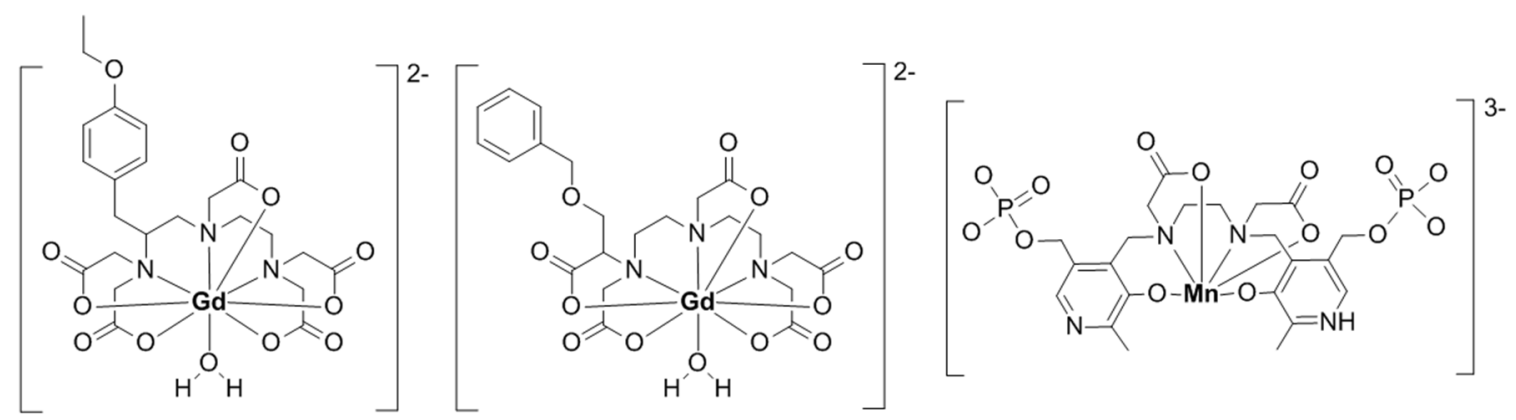

Figure 2. Structure of Gd-EOB-DTPA (left), Gd-BOPTA (middle), and Mn-DPDP (mangafodipir, right).

Excellent reviews have already highlighted the importance of Gd-EOB-DTPA in contrast-enhanced MRI, emphasizing its role in lesion characterization [11,17,29-31] and liver-function quantification [25] in different chronic liver diseases such as non-alcoholic fatty liver disease (NAFLD), liver fibrosis, and liver cirrhosis. Major application fields are also the pre-operative and post-operative evaluation of residual liver function, the volumetric assessment prior to resection [1,32], and the assessment of graft liver dysfunction $[11,21]$. Similar to Gd-BOPTA, application in MR cholangiography is also possible $[20,23,33]$.

Due to the similarities in hepatic uptake and excretion mechanisms, Gd-EOB-DTPA has repeatedly been compared with ${ }^{99}$ Tc-mebrofenin, an established liver-specific tracer used in nuclear medicine, and studies have found a good correlation between the results of these two imaging methods $[1,34]$. Due to the markedly higher temporal and spatial resolution and the absence of ionizing radiation, Gd-EOB-DTPA-enhanced MRI has, in fact, a great potential to be established as an imaging-based liver-function test offering an alternative to established hepatobiliary scintigraphy [1,34-39].

\subsection{Other Gd-Based Liver Imaging Agents}

Prior to the establishment of Gd-EOB-DTPA, approaches for liver targeting have focused on Gd-complexes of iminodiacetic acid (IDA) derivatives and lipophilic Gd-DTPA amides [40]. The complex Gd-DISIDA showed insufficient stability [40], while Gd-mebrofenin appeared to, in fact, have liver specificity, but showed a prolonged organ accumulation and limited biliary excretion [41]. The Gd-IDA complexes incorporated in a dendrimer carrier system also showed accumulation in the liver, albeit less than Gd-EOB-DTPA [42].

A new ligand, EOB-DO3A, has recently been developed, featuring a structure strongly related to EOB-DTPA but differing for the presence of a heptadentate macrocylic chelator in contrast to acyclic DTPA. The complex Gd-EOB-DO3A shows higher kinetic inertness than Gd-EOB-DTPA, promising less release of $\mathrm{Gd}(\mathrm{III})$ in vivo, while the rapid hepatic uptake (up to 50\%) and the biliary excretion observed in mice make it strongly similar to Gd-EOB-DTPA [43].

For tetraazacyclodecane derivatives bearing lipophilic groups like phenyl, butyl or benzyl moieties, it has been shown that there is a distinct difference between anionic Gd species (which are taken up by hepatocytes) and neutral Gd complexes (with limited hepatic uptake), emphasizing the importance of OATP-mediated liver uptake for metal complexes [44]. It has also been demonstrated that the lack of lipophilic moieties, especially in charged species, strongly enhances renal excretion [44]. Other lipophilic complexes exhibiting liver uptake and hepatobiliary excretion include anionic Gd-Cy 2 DOTA [45] and neutral Gd-2,5-BPA-DO3A [46,47].

Another approach is based on the complexation of Gd(III) with bile acids (conjugated to DOTA, DTPA or derivatives thereof $[48,49]$ ), based on the fact that bile acid analogues are in general strong targets of the liver. Bile acids are cholesterol derivatives, explaining the high liver uptake of a cholesterol-conjugated Gd-DO3A complex [50].

Conjugates of Gd-DTPA-polyneogalactosyl polylysine [51] and Gd-DOTA-arabinogalactan [52] target the asiaglycoprotein receptor (AGPR), which is expressed exclusively on mammalian hepatocytes. 
Targeting the AGPR is an established approach for liver targeting with ${ }^{99 \mathrm{~m}}$ Tc serum albumin scintigraphy, a method described later in Section 3.3.

Recently, research has focused on the incorporation of $\mathrm{Gd}$ chelates into nanoparticles or vesicles, e.g., liposomes. In general, this approach aims to decrease the toxicity of Gd-based CA and reduce the renal clearance, enabling the use in patients with renal impairment [12]. Additionally, the nanoparticle surface can be functionalized with specific targeting moieties. An early attempt to prepare Gd-DTPA-liposomes for liver MRI with a diameter of 200-300 $\mathrm{nm}$ has proved unsuccessful due to the risk of embolism [40]. In contrast, liposome-encapsulated Gd-DTPA of smaller size (50-100 nm) has been shown to successfully accumulate in the RES and slowly clear from the body [53], comparable to a liposome-encapsulated Gd-DTPA-stearate [54]. The Gd-labeled albumin-based nanoparticles were also taken up by the Kupffer cells $[55,56]$. Novel approaches are focused on enhancing the in vivo stability in order to prevent the release of $\mathrm{Gd}(\mathrm{III})$, as well as to enhance $\mathrm{T}_{1}$ and $\mathrm{T}_{2}$ relaxivities, enabling $\mathrm{T}_{1}-\mathrm{T}_{2}$ dual mode [57], and reduce the detection limit, thereby reducing the dose of $\mathrm{Gd}[56,58]$. In contrast, a different set of nanoparticles $(63-70 \mathrm{~nm})$ containing Gd(III) coordinated by lipid-bound DTPA has shown liver uptake and biliary excretion, with most agents being cleared from the body after $24 \mathrm{~h}$ [12]. Comparably small $(5 \mathrm{~nm}) \mathrm{Gd}$-based hybrid nanoparticles formed by bovine serum albumin have also been suggested as candidates for liver-specific MRI [59]. In general, the size of the nanoparticle determines the clearance dynamics [59].

\subsection{Side Effects of Gd-Based CA and Gd Deposition}

Due to the high doses (commonly applied doses are listed in Table 1 at the end of Section 3.4.) of Gd-based CA used for one scan and the well-known toxicity of free Gd(III), the stability of the complex and the potential release of Gd(III) from the ligand have always been a topic of concern when estimating the safety and applicability of a CA. According to the label of Gd-EOB-DTPA, common side effects include headache and nausea and less common effects include dizziness, flushing, pain, and itching [60]. The label of Gd-BOPTA states that more than $10 \%$ of the subjects enrolled in clinical trials experienced an adverse reaction, including nausea, headache, injection site reaction, and feeling hot [61]. The frequency of adverse events is comparable to that reported for Gd-EOB-DTPA [62]. An evaluation of six clinical phase IV studies reported that a total of $1.7 \%$ patients experienced at least one adverse event, the most frequent of which are dyspnea, nausea, and liver and renal disorders, concluding that Gd-EOB-DTPA is generally safe and well tolerated [63].

A general concern of Gd-based CA administration is the occurrence of immediate hypersensitivity reactions. A study based on 141,623 applications showed a total of 112 cases, with a higher incidence for Gd-BOPTA $(0.22 \%)$ than for Gd-EOB-DTPA $(0.12 \%)$. Two cases of severe reaction (i.e., life-threatening) were observed in a total of 84,367 patients, one for each CA [64]. Another study including 10,608 contrast-enhanced MRI examinations showed a $0.5 \%$ frequency of adverse reactions following Gd-BOPTA administration and $0.2 \%$ following Gd-EOB-DTPA administration [65]. Four cases of severe adverse reactions were observed, three of which with Gd-BOPTA; however, the differences did not prove statistically significant [65] Thus, Gd-BOPTA is considered generally safe, including in the pediatric population $[66,67]$.

A topic of concern associated with the use of Gd-based CA is the risk of developing nephrogenic systemic fibrosis (NSF), especially in patients with renal impairment [8,68-72]. Due to the reduced renal excretion rate, the prolonged blood half-life of the agents promotes dissociation of $\mathrm{Gd}(\mathrm{III})$ from the chelator and Gd deposition in tissue, which may cause a variety of pharmacological effects related with Gd(III)-toxicity, like RES inhibition and fibroblast proliferation, ultimately causing NSF [73]. Therefore, in this patient population, MRI is usually performed unenhanced or using reduced doses of CA [73]. Notably, however, Gd deposition has also been observed in the brain [74-76], skin [77], and skeleton [78] of patients with normal renal function. A systematic review on Gd deposition in brain and potential neurotoxicity has recently been published [74], in addition to other relevant reviews on the toxicity of Gd-based CA $[8,73,79]$. A general hypothesis is that-due to the similarity in 
size-free Gd(III) may compete with $\mathrm{Ca}(\mathrm{II})$, therefore affecting the function of $\mathrm{Ca}$ (II)-binding enzymes and calcium channels $[8,10]$. Animal experiments have shown that in depositions, $\mathrm{Gd}$ is found partly in the chemical form of intact CA, partly as insoluble $\mathrm{Gd}$, and partly bound to macromolecules [80].

The release of $\mathrm{Gd}(\mathrm{III})$ in the body is related with low kinetic inertness of several Gd-based CA, especially in the case of "linear" (i.e., open-chained) ligands like DTPA [10,68,80,81]. As a matter of fact, $\mathrm{Gd}$ deposition in the brain following repeated administration of CA has recently been associated even with macrocyclic agents like gadobutrol [82] and gadoteridol [83]. In 2017, the European Medicines Agency (EMA) suspended the marketing of three linear Gd-based CA [84]. The use of macrocylic agents is still allowed; however, only at the lowest possible dose and for justified cases in which unenhanced scans provide images of insufficient quality. The linear liver-specific CAs Gd-EOB-DTPA and Gd-BOPTA are considered to be of medium risk [68] and their use can be continued based on the fact that they are taken up mainly by the liver and meet an important diagnostic need [84]. There is an ongoing debate about whether the benefits of Gd-based CA application generally outweigh the risks, and individual decisions must be made based on medical indication and patient condition, especially considering the kidney function [85].

\subsection{Liver-Specific CA Based on Mn(II) and Other Metals}

Prior to the development of Gd-EOB-DTPA, the Mn(II) complex of DPDP [86]—mangafodipir (Figure 2)-was clinically approved in the 1990s as a hepatobiliary CA. Mangafodipir-enhanced MRI improved the identification of HCC $[18,87,88]$ and more generally the detection, classification, and diagnosis of focal liver lesions (Figure 3) [24,89-92], including primary and metastatic liver tumors [93,94]. Excellent articles have been published comparing liver-specific Gd-EOB-DTPA, Gd-BOBPTA, and Mn-DPDP with detailed descriptions of detection rates, contrast enhancement on various types of lesions, and influence on the respective acquisition techniques [90].

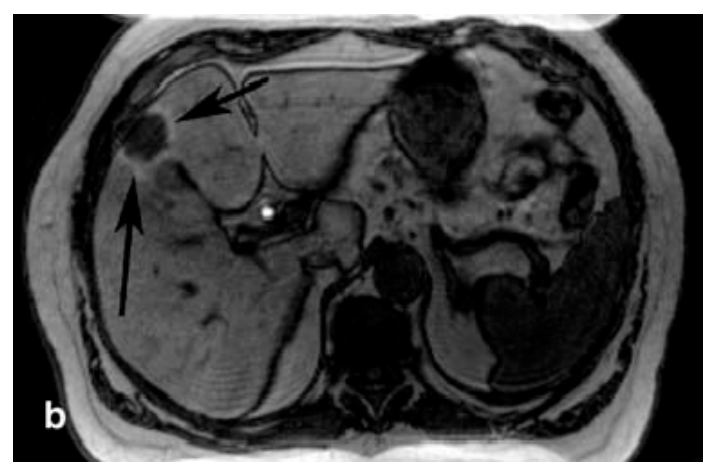

Figure 3. Mangafodipir-enhanced MRI of the liver showing the presence of hepatocellular carcinoma lesions (arrows). Reprinted with permission from Reference [90].

A $15-20 \%$ fraction of Mn-DPDP is excreted via the kidneys, 50-60\% via the feces [90,95-97]. Following i.v. injection, Mn-DPDP is metabolized via dephosphorylation and transmetallation with zinc $[96,97]$. Demetallation is substantial, and release of Mn(II) occurs rapidly $[98,99]$. While the ligand is excreted via the kidneys [18], free $\mathrm{Mn}(\mathrm{II})$ accumulates in the liver, leading to three-fold $\mathrm{T}_{1}$ relaxivity compared to Gd(III) [90,99], after which it is excreted into the bile [100]. Liver parenchymal enhancement begins $1 \mathrm{~min}$ p.i., with subsequent clearance into the gall bladder after $15 \mathrm{~min}$ [101]. Excretion from the liver is relatively slow (6-23 h p.i.) [93]. The agent Mn-DPDP also exhibits accumulation in spleen, pancreas, and kidneys [14,93] due to the release of free $\mathrm{Mn}(\mathrm{II})$ in the blood $[98,99]$.

In contrast to toxic $\mathrm{Gd}(\mathrm{III}), \mathrm{Mn}$ is an essential trace element in the body and is excreted via natural ways. The dose of Mn-DPDP applied for a routine MRI $(5 \mu \mathrm{mol} / \mathrm{kg}[18,90])$ contains approximately the same amount of Mn as the normal content of the whole human body [90]. Nonetheless, release of Mn(II) from the complex into the blood and possible neurotoxicity of free $\mathrm{Mn}(\mathrm{II})$ has been discussed from 
the very beginning $[87,98-100,102,103]$. Free $\mathrm{Mn}(\mathrm{II})$ has been associated with extensive production of reactive oxygen species (ROS) [104,105], reactive nitrogen species (RNS) [106], and also with mitochondrial manganese superoxide dismutase (MnSOD) mimetic activities [107]. Also, possible adverse cardiovascular responses such as negative inotropy and vasodilation were suspected to occur based on the fact that $\mathrm{Mn}$ (II) - particularly if released at high extracellular concentrations-may act as a clinically-relevant $\mathrm{Ca}$ (II) antagonist $[88,108,109]$. However, early studies focused on toxicity and cardiovascular effects have concluded that Mn-DPDP is generally safe in normal clinical use $[90,110,111]$.

In a phase III study, $17 \%$ of patients experienced mild to moderate adverse events after exposure to Mn-DPDP [95]. The side effects included flushed face, hot feeling on head and ears, reactive increase of blood pressure, and postural hypotension in cases of overdosing $[87,93,97-99,103,108,112]$. Based on this safety profile, injection of Mn-DPDP must proceed per slow-drip infusion rather than per bolus [14,93,98]. Mangafodipir was removed from the market in 2012 due to the fact of poor sales [87]; however, the recent concerns of Gd-related NSF have sparked a renewed interest in Mn-based CA as alternatives to Gd-based CA [100,113].

A promising new agent enabling MR angiography, exhibiting both renal and hepatobiliary clearance, is $\mathrm{Mn}(\mathrm{PyC} 3 \mathrm{~A})$ [114,115]. Lipophilic derivatives of Mn(PyC3A) also showed hepatocellular accumulation with $\mathrm{Mn}(\mathrm{PyC} 3 \mathrm{~A}-3-\mathrm{OBn})$ being a potential replacement of standard Gd-based liver CA $[116,117]$. A liver-specific Mn-based CA (benzothiazole aniline conjugated ethylenediamine tetraacetic acid (EDTA)) of higher stability than Mn-DPDP was reported in 2017. This CA exhibits hepatobiliary and renal excretion (similarly to Gd-EOB-DTPA) and enables tumor localization in a xenograft mouse model, with tumor-to-tissue contrast superior to that observed with Mn-DPDP [118]. Trapping of alkylated Mn(II) complexes into liposomes has also shown hepatic enhancement in rats [100], and an Mn(II) chelating EDTA-based dendrimer (excreted both via the kidneys and hepatobiliary system) has been discussed as a possible CA for imaging of the liver and the hepatobiliary tree [119]. A liver-specific Cr(III)-diethyl-HIDA complex as CA was reported as early as in 1990; however, this compound has shown insufficient liver contrast enhancement [120].

Besides hepatocytes, a major component of the liver tissue are Kupffer cells, i.e., resident macrophages responsible for the metabolism of small particles, lipids, and proteins [121]. The Kupffer cells represent only approximately $15 \%$ of the liver but as much as $90 \%$ of the whole body RES [2], therefore any CA targeting the RES can be basically considered liver-specific. Imaging of the liver with (ultra) superparamagnetic iron oxides (SPIOs or USPIOs), which typically accumulate in the Kupffer cells, enables the identification of lesions that do not contain Kupffer cells [14]. Sensitivity can be enhanced by doping iron oxides with Mn [122]. Dynamic imaging is possible when the particulate CA can be administered as a bolus, which depends on the particle size [14]. Patients often react with backache to SPIO administration, making slow infusion necessary [18]. In general, colloids do not exhibit notable biliary excretion but they persistently accumulate in the RES over days, until they are destroyed [18]. As these particles are based on iron oxide and do not feature coordinative metal bonds, these agents are not further discussed in this review. Another recently proposed compound with relevant accumulation in the Kupffer cells is a Fe(III) melanoidin chelate. This compound has shown a good contrast between HCC and healthy liver tissue in a mouse model, and represents a potentially safer CA than agents based on Mn and Gd [123].

\section{Metal Complexes in Scintigraphic Liver Imaging}

\subsection{Scintigraphic Imaging and Relevant Metal Nuclides}

In scintigraphy, single photons emitted by gamma nuclides are detected via scintillation crystals and translated into electric signals [6]. While one gamma camera can only record a planar image, single photon emission computed tomography (SPECT) enables three-dimensional imaging via tomographic reconstruction using several gamma heads. 
Since collimators are needed to reduce scatter photons, SPECT is less sensitive than positron emission tomography (PET) and requires long scan times, hence limiting the temporal resolution necessary for dynamic imaging [15,124]. However, SPECT imaging continues to be improved with new pin-hole techniques enabling spatial resolution in the sub-millimeter range $[15,124]$. Spatial resolution also strongly depends on the energy of the emitted gamma photons. ${ }^{99 \mathrm{~m}} \mathrm{Tc}$ has become the isotope of choice for nuclear medicine applications, due to its favorable gamma energy of $140 \mathrm{keV}$, short half-life (6 h), feasibility of pharmaceutical synthesis using ${ }^{99} \mathrm{Mo} /{ }^{99 \mathrm{~m}} \mathrm{Tc}$ generators, and wide availability of established kits $[125,126]$. ${ }^{99 \mathrm{~m}} \mathrm{Tc}$ coordination chemistry has been extensively investigated for decades, offering a wide range of specific chelators for a variety of diagnostic purposes, including tumor targeting, organ-specific imaging (including kinetic modelling), and brain imaging [125,127]. Other metal nuclides used in scintigraphy include ${ }^{111} \mathrm{In},{ }^{67} \mathrm{Ga}$, and ${ }^{201} \mathrm{Tl}$; however, ${ }^{111} \mathrm{In}$ and ${ }^{67} \mathrm{Ga}$ emit gamma photons of higher energy than ${ }^{99 \mathrm{~m}} \mathrm{Tc}$, hence requiring stronger collimation and resulting in lower image resolution.

The general advantage of nuclear medical imaging over MRI is the much higher sensitivity of the detection systems and the absence of a background signal [1]. In MRI, all protons in the body are excited by the radiofrequency pulse, while in nuclear medicine, the signals are selectively detected from the sites with radiopharmaceutical accumulation. This is the reason why high doses of CA are needed in MRI (in the range of 1-10 mmol), whereas the concentrations of radiopharmaceuticals needed for nuclear medicine imaging usually lie in the pico- or nanomolar range $[5,6,15]$, and are therefore devoid of adverse pharmacological effects. This dosage gap highlights the importance of continuous research focused at increasing the availability and improving the safety profile of CA for MRI.

\section{2. ${ }^{99 m} \mathrm{Tc}$-Complexes for Hepatobiliary Scintigraphy}

The ${ }^{99 \mathrm{~m}}$ Tc-labeled derivatives of phenylcarbamoylmethyl iminidoacetic acid (IDA), a lidocaine analogue [35], have been developed since the 1970s [128]. Originally intended for the diagnosis of biliary diseases [2,129-133], the application field has broadened from hepatobiliary scintigraphy (also called cholescintigraphy) to assessment of global and regional liver function and functional liver volume [134], allowing for three-dimensional liver volumetry via SPECT/CT [1]. However, due to the relatively low spatial resolution, this approach is not feasible for liver lesion differentiation [34].

The ${ }^{99 \mathrm{~m}} \mathrm{Tc}-\mathrm{IDA}$ biscomplexes generally exhibit rapid hepatic uptake, with a biological half-life in blood of only 3-5 min [135]. Cholescintigraphy is usually performed via dynamic imaging. Scans are acquired immediately following i.v. injection of the CA, with acquisition timeframes of 2-10 s within the first $2 \mathrm{~min}$. In this early phase, the vascularity visualization is similar to that of extracellular CA. Acquisition timeframes are then prolonged first to 15-30 s and then, after the beginning of the parenchymal phase at between 10-20 min p.i., the timeframes are prolonged to $2 \mathrm{~min}$ per frame [129]. Under normal circumstances, excretion into the gallbladder starts at about $15 \mathrm{~min} p . i$. , followed by excretion into the duodenum at $20 \mathrm{~min}$ p.i., and by complete clearance from the liver parenchyma after $60 \mathrm{~min}$ (Figure 4) [2,129]. In cases of bile duct obstruction or reduced duodenal activity, late-stage imaging can be additionally performed between $2-3 \mathrm{~h}$ and $24 \mathrm{~h} p . i$. [129]. Detailed reviews have been published on the application and relevance of ${ }^{99 \mathrm{~m}}$ Tc-mebrofenin in liver function tests $[132,133,136,137]$.
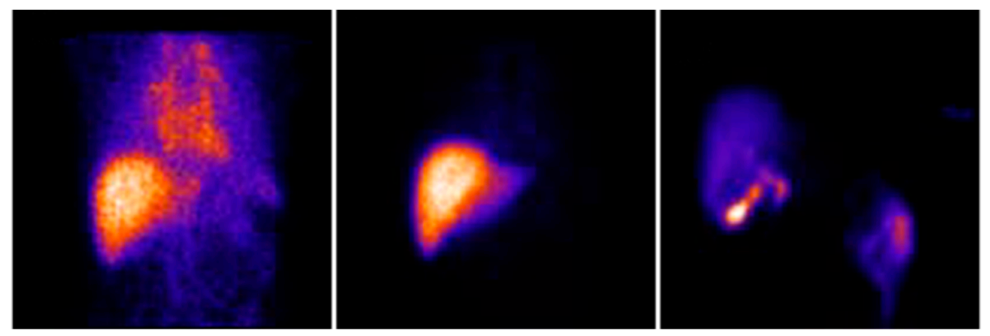

Figure 4. Dynamic planar cholescintigraphy with ${ }^{99 \mathrm{~m}} \mathrm{Tc}-$ Mebrofenin showing normal hepatic uptake and blood clearance in the early phase (left and middle) and biliary excretion in the late phase (right). Adapted and reprinted with permission from Reference [132]. 
The ${ }^{99 \mathrm{~m}}$ Tc-mebrofenin, (BRIDA, 3-bromo-2,4,6-trimethyl-IDA (Figure 5)) shows a very high hepatic uptake (>98\%) [138] and minimal renal excretion [132,139], and is therefore the most widely used clinical standard for cholescintigraphy [1,140]. Another common radiopharmaceutical is ${ }^{99 \mathrm{~m}}$ Tc-etifenin (2,6-diethyl-IDA, EHIDA, (Figure 5)) [141], which exhibits slightly lower hepatic uptake (82\%) than ${ }^{99 \mathrm{~m}} \mathrm{Tc}-\mathrm{mebrofenin}$ but a longer biliary excretion half-life $(37 \mathrm{~min})$ than ${ }^{99 \mathrm{~m}} \mathrm{Tc}-\mathrm{mebrofenin}(17 \mathrm{~min})$. The highest parenchymal activity for ${ }^{99 \mathrm{~m}} \mathrm{Tc}-$ mebrofenin and ${ }^{99} \mathrm{~m}$ Tc-etifenin is visible already at $1 \mathrm{~min}$ p.i. [141,142]. The ${ }^{99 \mathrm{~m}} \mathrm{Tc}-\mathrm{IDAs}$ bind to serum albumin and are released when they reach the space of Disse in the liver $[35,133,138,139,143]$. The hepatic uptake proceeds via OATPB1 and OATP1B3 [1,34, $35,134,144]$, similarly to Gd-EOB-DTPA. The ${ }^{99 \mathrm{~m}}$ Tc-IDAs are excreted unmetabolized into the bile [141] by the same mechanism as bromosulfophthalein and bilirubin $[1,132,134,135,143]$, thus explaining why elevated bilirubin levels can strongly inhibit hepatospecific uptake and increase renal excretion of ${ }^{99 \mathrm{~m}}$ Tc-IDAs $[135,143,145]$. However, the strength of hepatic uptake inhibition largely depends on the structure of the ${ }^{99 \mathrm{~m}} \mathrm{Tc}-\mathrm{IDA}$ compound [143]. For example, hepatic uptake of ${ }^{99 \mathrm{~m}} \mathrm{Tc}-\mathrm{mebrofenin}$ has proven resistant to high bilirubin levels $[139,143]$, which is another reason why this is the most popular tracer in hepatobiliary scintigraphy, although it should be considered that, since albumin is the main plasma carrier of ${ }^{99 \mathrm{~m}} \mathrm{Tc}-$ mebrofenin, the liver uptake can be hindered in patients with hypoalbuminemia [140]. Prior to the establishment of ${ }^{99 \mathrm{~m}}$ Tc-mebrofenin and ${ }^{99 \mathrm{~m}}$ Tc-etifenin, various IDA derivatives have been developed as potential hepatobiliary CA, including DISIDA (disofenin [146-150]), HIDA (lidofenin) [139], PIPIDA [143], IOTIDA [151], diethylmonoiodo-IDA [152], as well as IDAs conjugated to phthalein and fluorescein moieties [153], to name only a few [139].

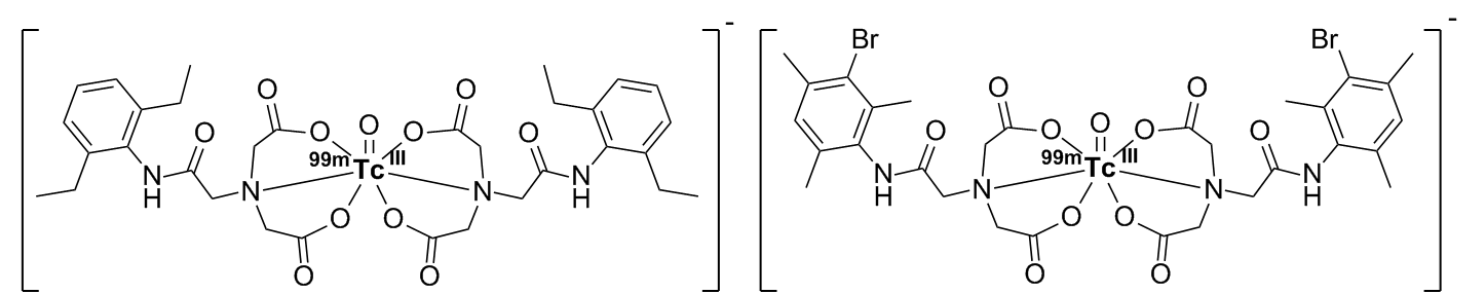

Figure 5. Structure of ${ }^{99 \mathrm{~m}} \mathrm{Tc}$-etifenin (left) and ${ }^{99 \mathrm{~m}} \mathrm{Tc}-\mathrm{meb}$ rofenin (right).

The ${ }^{99 \mathrm{~m}} \mathrm{Tc}$ complexes of pyridoxylidene amino acids have also been applied for hepatobiliary scintigraphy $[135,154,155]$, and one of these tracers, ${ }^{99 \mathrm{~m}} \mathrm{Tc}-\mathrm{PMT}$, is still used in clinical routine in Japan [156-159]. Due to the fact of its specific hepatic uptake, it is also possible to identify bone metastasis of HCC [160]. Within $30 \mathrm{~min}$, over $90 \%$ of the applied dose of ${ }^{99 \mathrm{~m}} \mathrm{Tc}-\mathrm{PMT}$ is passed through the liver, with the highest uptake appearing at about $8 \mathrm{~min} p . i$. [138]. Liver uptake is mediated by OATPB1 and OATP1B3 just as for ${ }^{99 \mathrm{~m}}$ Tc-IDAs and the complex is excreted into the bile unmetabolized [158].

In an attempt to optimize the properties of the ${ }^{99 \mathrm{~m}} \mathrm{Tc}$ complexes as hepatobiliary tracers, extensive studies in structure-distribution relationships have focused on the correlation between substitution pattern, lipophilicity, hepatic uptake, and excretion rates $[135,139,143]$. Increased lipophilicity due to the fact of para-substitution, for example, increases albumin binding of ${ }^{99 \mathrm{~m}} \mathrm{Tc}-\mathrm{IDA}$ in the blood, which again increases hepatic uptake and decreases renal excretion, while ortho-substitution tends to increase renal excretion $[138,143,161]$. While a high level of lipophilicity generally increases hepatic extraction, it also prolongs the hepatic transit time, thereby degrading the quality of biliary imaging $[135,139,143]$. Apparently, a greater number of small alkyl substituents (like methyl) is beneficial over a single, larger, and more lipophilic substituent (like isopropyl) in reducing the hepatobiliary transit time, especially if the alkyl substituents are in ortho-position [139]. Similar observations have been made for ${ }^{99 m}$ Tc-pyridoxylidenephenylalanine [155].

More recent variations of established ${ }^{99 \mathrm{~m}} \mathrm{Tc}$-IDAs include carbonyl ligands [161]. Another approach is to exploit the imaging potential of bile acids, since these are natural ligands recognized by the 
liver [162]. Thus far, attempts have focused on ${ }^{99 \mathrm{~m}} \mathrm{Tc}$ and ${ }^{111} \mathrm{In}$ complexes of bile acid conjugates, which have shown hepatobiliary uptake and excretion [162,163].

\section{3. ${ }^{99 m}$ Tc Serum Albumin Scintigraphy and Asiaglycoprotein Receptor Imaging}

The asiaglycoprotein receptor (AGPR) is exclusively expressed on mammalian hepatocytes. Damaged liver tissue usually exhibits reduced AGPR expression, which enables estimation of functional liver volume [140,164]. Targeting this receptor with ${ }^{99 \mathrm{~m}}$ Tc-DTPA-galactosyl serum albumin (GSA) conjugated with asiaglycoprotein (AGP) is used to determine the regional hepatic function (Figure 6) $[1,35,133,140,165]$. This approach has been developed from an original formulation containing galactosyl-neoglycoalbumin (NGA) [166] and is available as a kit in Japan. Excellent reviews have been published regarding the role of ${ }^{99 \mathrm{~m}} \mathrm{Tc}-\mathrm{GSA}$ in quantification of functional hepatic mass $[1,35,133,140]$.

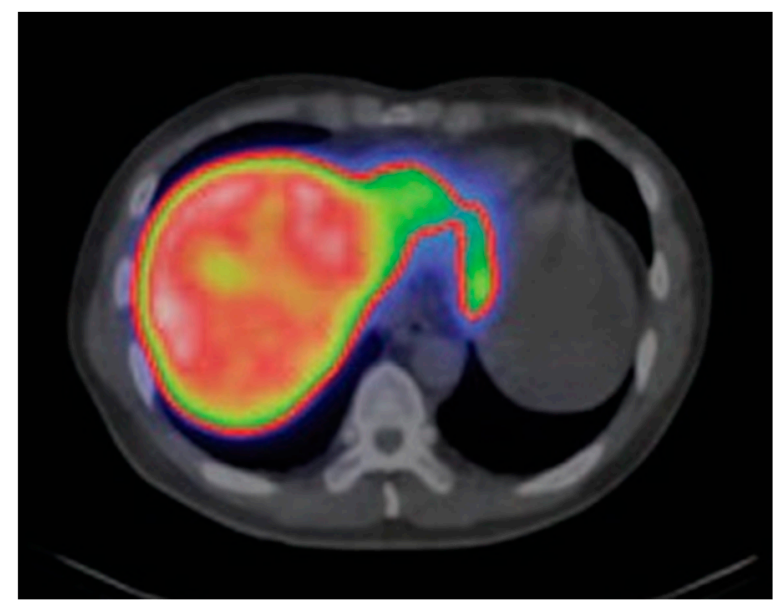

Figure 6. Single photon emission computed tomography (SPECT/CT) scan showing ${ }^{99 m}$ Tc-DTPA-galactosyl serum albumin (GSA) accumulation in a fibrotic liver. Reprinted with permission from Reference [167].

The ${ }^{99 \mathrm{~m}} \mathrm{Tc}$-labeled galactosylated copolymers based on styrene were developed with the aim to decrease blood circulation time and reduce the potential immunogenicity of ${ }^{99 \mathrm{~m}} \mathrm{Tc}-\mathrm{GSA}$. These copolymers show high liver uptake (comparable to ${ }^{99 \mathrm{~m}} \mathrm{Tc}-\mathrm{GSA}$ ) but faster blood clearance [168, 169], and have proven successful for the assessment and staging of hepatic fibrosis in mouse models [170]. One copolymer was further developed for use as a SPECT/MRI dual modality imaging agent by adding DTPA moieties into the monomers, thus additionally enabling chelation of Gd(III) [171]. Liver-targeting ${ }^{99 \mathrm{~m}} \mathrm{Tc}$ labeled polymers with galactosylated chitosan [172] and dextran [173] have also been developed, with the chitosan-based tracers also exhibiting high renal excretion [172]. Unlike the OATP-mediated uptake of ${ }^{99 \mathrm{~m}} \mathrm{Tc}-I D A s$, all ${ }^{99 \mathrm{~m}} \mathrm{Tc}$-labeled AGPR-targeting complexes are taken up by the hepatocytes via receptor-mediated endocytosis [169]; however, they are not excreted in the bile and, therefore, cannot be used for the diagnosis of biliary diseases [140,169].

Conjugates of NGA labeled with ${ }^{111}$ In have shown hepatic accumulation in mice [174]. Hexavalent lactoside modified with DTPA to chelate ${ }^{111}$ In also exhibited nearly exclusive accumulation in rat and mice liver [175-177]. ${ }^{111}$ In complexes of DTPA derivatives bearing aromatic moieties also exhibit mainly hepatobiliary excretion, comparably to their Gd(III) analogs $[178,179]$.

The tracer ${ }^{67} \mathrm{Ga}$ citrate can be applied for the detection of HCC, due to the fact of its accumulation in tumors expressing the transferrin receptor [180-182]. Since citrate is a weak chelator for ${ }^{67} \mathrm{Ga}$, transmetallation to transferrin occurs in vivo [181]. However, ${ }^{67} \mathrm{Ga}$ citrate is quite unspecific, also showing high activity in the blood pool and accumulation in inflammatory tissue [183]. Furthermore, ${ }^{67} \mathrm{Ga}$ citrate can also be used to identify liver defects in cirrhosis, comparably to ${ }^{99 \mathrm{~m}}$ Tc colloid [184]. 


\subsection{Colloid Scintigraphy}

Colloid scintigraphy with ${ }^{99 \mathrm{~m}} \mathrm{Tc}$-sulfur colloid, ${ }^{99 \mathrm{~m}} \mathrm{Tc}$-tin colloid, ${ }^{99 \mathrm{~m}} \mathrm{Tc}-$ phytate, and ${ }^{99 \mathrm{~m}} \mathrm{Tc}$ albumin colloid is one of the earliest liver imaging techniques [2,129]. Since these tracers mainly target the RES, they do not show notable biliary excretion but accumulate persistently in the Kupffer cells, thereby allowing the visualization of heterogeneities in liver uptake and storage defects, and also enabling scintigraphic liver volumetry [2]. Although of more limited importance compared to hepatobiliary tracers, ${ }^{99 \mathrm{~m}} \mathrm{Tc}$-sulfur colloid scintigraphy is still in use, e.g., for the determination of regional liver function with SPECT [185] and identification of diffuse liver diseases like cirrhosis [186]. Enhanced uptake of colloid in RES regions other than the liver, for example bone marrow and spleen, can indicate cirrhosis [187].

${ }^{99 \mathrm{~m}} \mathrm{Tc}$ phytate can be used similarly to ${ }^{99 \mathrm{~m}} \mathrm{Tc}$-sulfur colloid [188-190]. Although it is a ${ }^{99 \mathrm{~m}} \mathrm{Tc}$ complex, following i.v. injection ${ }^{99 \mathrm{~m}} \mathrm{Tc}$ phytate rapidly binds to calcium in serum, therefore behaving like a nanoparticle [191].

Table 1. List of commercially available metal complexes applicable in MRI and SPECT liver imaging.

\begin{tabular}{|c|c|c|c|c|}
\hline & $\begin{array}{l}\text { Complex (Commercial } \\
\text { Source: Tradename) }\end{array}$ & $\begin{array}{c}\text { Biodistribution }^{1 /} / \text { Target } \\
\text { Excretion }\end{array}$ & Use and Limitations & Applied Dose \\
\hline \multirow{4}{*}{ 芯 } & $\begin{array}{l}\text { Gd-DTPA (Bayer: } \\
\left.\text { Magnevist }{ }^{\circledR}\right)\end{array}$ & $\begin{array}{c}\text { extracellular, } \\
\text { non-specific, renal } \\
\text { excretion }\end{array}$ & $\begin{array}{l}\text { lesion characterization, only } \\
\text { early phase visualization }\end{array}$ & $\begin{array}{c}0.1-0.2 \mathrm{mmol} / \mathrm{kg} \\
{[23]}\end{array}$ \\
\hline & $\begin{array}{l}\text { Gd-EOB-DTPA (Bayer: } \\
\text { Primovist }{ }^{\circledR}, \text { Eovist }^{\circledR} \text { ) }\end{array}$ & $\begin{array}{l}\text { uptake by hepatocytes } \\
(50 \%) \text { with biliary } \\
\text { excretion }\end{array}$ & \multirow{2}{*}{$\begin{array}{l}\text { lesion characterization in } \\
\text { early and late phase, } \\
\text { cholangiography, } \\
\text { Gd-EOB-DTPA can be used } \\
\text { for liver volumetry, } \\
\text { quantification and liver } \\
\text { function test }\end{array}$} & $\begin{array}{c}0.025-0.05 \\
\mathrm{mmol} / \mathrm{kg}[60]\end{array}$ \\
\hline & $\begin{array}{c}\text { Gd-BOPTA (Bracco } \\
\text { Diagnostic: } \\
\text { MultiHance }^{\circledR} \text { ) }\end{array}$ & $\begin{array}{l}\text { uptake by hepatocytes } \\
(5 \%) \text { with biliary } \\
\text { excretion, mostly renal } \\
\text { excretion }\end{array}$ & & $\begin{array}{c}0.05-0.1 \mathrm{mmol} / \mathrm{kg} \\
{[23]}\end{array}$ \\
\hline & $\begin{array}{l}\text { Mn-DPDP (GE } \\
\text { Healthcare: Teslascan }{ }^{\circledR} \text { ) }\end{array}$ & $\begin{array}{l}\text { dissociation in vivo, } \\
\text { uptake of } \mathrm{M}(\mathrm{II}) \text { by } \\
\text { hepatocytes }(>60 \%) \text {, } \\
\text { biliary excretion }\end{array}$ & $\begin{array}{l}\text { lesion characterization, } \\
\text { cholangiography, no bolus } \\
\text { injection }\end{array}$ & $5 \mu \mathrm{mol} / \mathrm{kg}$ [90] \\
\hline \multirow{5}{*}{ 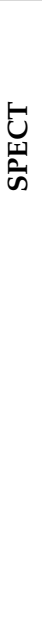 } & $\begin{array}{c}\text { 99m Tc-mebrofenin } \\
\text { (Bracco Diagnostic: } \\
\text { Choletec }{ }^{\circledR} \text {, or GE } \\
\text { Healthcare: Bridatec }{ }^{\circledR} \text { ) }\end{array}$ & $\begin{array}{l}\text { uptake by hepatocytes } \\
(>98 \%) \text { with biliary } \\
\text { excretion }\end{array}$ & \multirow{3}{*}{$\begin{array}{l}\text { hepatobiliary scintigraphy, } \\
\text { liver volumetry, liver } \\
\text { function test, diagnosis of } \\
\text { chronic liver diseases, no } \\
\text { lesion differentiation }\end{array}$} & $\begin{array}{c}0.06 \mathrm{mmol}^{2} \text { per kit } \\
{[142]}\end{array}$ \\
\hline & $\begin{array}{c}{ }^{99 m} \text { Tc-etifenin (ROTOP: } \\
\text { EHIDA }^{\circledR} \text { ) }\end{array}$ & $\begin{array}{l}\text { uptake by hepatocytes } \\
(82 \%) \text { with biliary } \\
\text { excretion }\end{array}$ & & $\begin{array}{c}0.06 \mathrm{mmol}^{2} \text { per kit } \\
{[141]}\end{array}$ \\
\hline & $\begin{array}{c}99 \mathrm{~m} \text { Tc-PMT (Japan } \\
\text { Medi-Physics Co., Chiba } \\
[158])\end{array}$ & $\begin{array}{l}\text { uptake by hepatocytes } \\
(>90 \%) \text { with biliary } \\
\text { excretion }\end{array}$ & & $6.0 \mathrm{mmol}^{2}$ per kit \\
\hline & $\begin{array}{c}\text { 99m Tc-GSA (Nihon } \\
\text { Medi-Physics, Tokyo } \\
\text { [192]) }\end{array}$ & $\begin{array}{l}\text { exclusive uptake by } \\
\text { AGPR on hepatocytes, } \\
\text { no excretion }\end{array}$ & \multirow{2}{*}{$\begin{array}{l}\text { liver volumetry, regional } \\
\text { hepatic function, diagnosis } \\
\text { of chronic liver diseases, no } \\
\text { visualization of biliary } \\
\text { structures }\end{array}$} & $0.04 \mu_{3}^{\mathrm{mol}^{2}}$ per kit \\
\hline & $\begin{array}{l}\text { 99m Tc-Phytate (Curium: } \\
\left.\text { Phytacis }{ }^{\circledR}\right)\end{array}$ & $\begin{array}{l}\text { uptake in Kupffer cells } \\
\text { (75\% liver), no excretion, } \\
\text { phagocytosis }\end{array}$ & & $\begin{array}{c}0.03 \mathrm{mmol}^{2} \text { per kit } \\
{[193]}\end{array}$ \\
\hline
\end{tabular}

${ }^{1}$ Liver uptake can differ considerably from the given values, e.g., in cases of inhibited liver function or high bilirubin levels. ${ }^{2}$ Since the amount of radioactive ${ }^{99 \mathrm{~m}} \mathrm{Tc}$-complex in all formulations lies in the range of nanomoles, the given number refers to the amount of non-labelled ligand, which is commonly present in large excess compared to the radioactive compound. ${ }^{3}$ Calculated from the amount of GSA per kit $(3 \mathrm{mg})$ and a molecular weight for GSA of $80.730 \mathrm{Da}$ [192]. DTPA: diethylenetriamine pentaacetic acid, EOB-DTPA: p-ethoxybenzyl-DTPA, BOPTA: benzyloxymethyl-DTPA, DPDP: dipyridoxylethylendiamindiacetatediphosphate, mebrofenin: 3-bromo-2,4,6-trimethyl-iminodiacetic acid, etifenin: 2,6-diethyl-iminodiacetic acid, PMT: $\mathrm{N}$-pyridoxyl-5-methyltryptophane, GSA: galactosyl serum albumin. 


\section{Metal Complexes in Liver Specific Pet Diagnostics}

\subsection{PET Imaging and Relevant Metal Nuclides}

Compared to scintigraphy, which emerged with the first gamma camera in the 1950s [194], PET has been established for clinical routine only since the early 1990s and is therefore the most recent method of molecular imaging presented in this review.

Positrons emitted by PET radionuclides possess only a short half-life in matter. The distance covered by a positron before annihilation (positron range) ultimately determines and limits the spatial resolution of PET. The positron range lies in the order of a few millimeters and is characteristic for each nuclide since it depends on the positron energy. The annihilation of positrons with electrons results in the generation of two photons with a characteristic energy of $511 \mathrm{keV}$. These annihilation photons are simultaneously emitted into opposite directions and are detected by scintillation crystals, and the short time window between the detection (coincidence) determines the detection event being processed as "true" or "false" $[15,195]$. Because of the electronic collimation used in PET (compared to the physical collimation used in SPECT), PET is more sensitive than SPECT and exhibits a higher spatial resolution $[6,15,124,196]$. Scintillation crystals are arranged in a detector ring surrounding the patient, thereby providing three-dimensional imaging with a high temporal resolution. Hence, the main advantages of PET is the possibility to perform dynamic imaging and, in addition, to obtain a quantification of the tracer activity [6].

The most commonly used metal nuclide in PET is ${ }^{68} \mathrm{Ga}[197,198]$. The main reason for its importance is that it can be produced via a portable, reusable generator system from the mother nuclide ${ }^{68} \mathrm{Ge}$, thus circumventing the need of a cyclotron, required for non-metal PET nuclides such as ${ }^{18} \mathrm{~F}$ and ${ }^{11} \mathrm{C}[127,199-202]$. The ${ }^{68} \mathrm{Ga}$ nuclide has a half-life of $68 \mathrm{~min}$, allowing time for radiopharmaceutical production [195,202]. Similar to ${ }^{99 \mathrm{~m}}$ Tc species in SPECT, ${ }^{68} \mathrm{Ga}$-tracer synthesis is mainly based on coordinative chemistry, enabling efficient and fast binding of the metal to a specific chelator. There is a continuously growing interest in developing ${ }^{68} \mathrm{Ga}$ tracers via kit production (comparably to established ${ }^{99 \mathrm{~m}} \mathrm{Tc}$ radiopharmaceutical synthesis) allowing quick, easy, and safe production independently of PET centers or cyclotron production sites $[198,200]$. Other radiometals of growing interest include ${ }^{64} \mathrm{Cu}$, ${ }^{44} \mathrm{Sc}$, and ${ }^{89} \mathrm{Zr}$, although none of them are currently used in clinical routine [126,198].

\subsection{Advances in the Development of Liver Specific PET Tracers}

Compared to SPECT, PET exhibits superior spatial resolution, therefore the imaging of liver lesions is well established using standard non-metal PET tracers like ${ }^{18}$ F-FDG [203,204] and ${ }^{11} \mathrm{C}$-acetate [205]. Since $\mathrm{Ga}(\mathrm{III})$ is a biomimetic of $\mathrm{Fe}(\mathrm{III})$, injection of ${ }^{68} \mathrm{Ga}$-citrate selectively leads to the formation of ${ }^{68} \mathrm{Ga}$-transferrin in vivo, which enables the imaging of tumors expressing the transferrin receptor [206]. However, ${ }^{68}$ Ga-transferrin also exhibits a high blood pool activity and accumulation in the lungs, thus resulting in high background activity [207].

Attempts to develop a radiometal complex for functional liver PET imaging reaches far back [208], but to the best of our knowledge none of these potential PET radiotracers has gone beyond the preclinical testing stage. The rationale for developing metal tracers that exhibit comparable hepatic uptake and biliary excretion clearly lies in the translation of structures from well-known liver pharmaceuticals for SPECT and MRI CA. A promising attempt to perform liver function imaging with PET is based on an IDA conjugate of bromocresolphthalein, a suitable ligand for ${ }^{68} \mathrm{Ga}$ [208]. The tracer shows high liver accumulation (60\% injected dose (ID)); however, biliary excretion is comparably slow and does not exceed 15\% ID [208]. While non-modified IDA is per se not a suitable ligand for ${ }^{68} \mathrm{Ga}$ due to the rapid demetallation (as shown for ${ }^{68} \mathrm{Ga}$-etifenin [209]), the additional phenolic coordination site on the cresolphthalein moiety provides a more suitable coordination sphere for ${ }^{68} \mathrm{Ga}$ [208]. An example of an anionic lipophilic complex is ${ }^{68} \mathrm{Ga}-t$-butyl-HBED, which has shown rapid liver accumulation and hepatobiliary clearance in primates [210]. A trichatecholamide analogue of enterobactin, ${ }^{68} \mathrm{Ga}$-3,4-DiP-LICAM, has also been discussed as a possible tracer to study hepatobiliary 
kinetics [211], whereas ${ }^{68} \mathrm{Ga}$-alizarin has been presented as a possible RES imaging agent [212]. Comparable to ${ }^{99 \mathrm{~m}}$ Tc-sulfur-colloid scintigraphy, ${ }^{68} \mathrm{Ga}$-labeled iron hydroxide colloid presents high liver accumulation [213].

With the intent to target the AGPR, the translation of ${ }^{99} \mathrm{~m}$ Tc-NGA and ${ }^{99} \mathrm{~m}$ Tc-GSA, respectively, into a ${ }^{68} \mathrm{Ga}$ analogue requires a change in the binding motif to achieve a stable coordination of ${ }^{68} \mathrm{Ga}$. Deferoxamine-NGA labeled with ${ }^{67} \mathrm{Ga}$, developed already in 1992, shows $90 \%$ hepatic uptake [214]; therefore, a similar biodistribution can be expected from a ${ }^{68} \mathrm{Ga}$-based PET analogue. While DTPA-GSA is a suitable ligand for ${ }^{99} \mathrm{~m} \mathrm{Tc},{ }^{68} \mathrm{Ga}-\mathrm{DTPA}-\mathrm{GSA}$ has shown specific liver accumulation but poor stability in vivo [192]. The stability could be sufficiently improved by exchanging the chelator DTPA with the well-known ${ }^{68} \mathrm{Ga}$ chelator NOTA (Figure 7) [215]. A similar attempt was undertaken with NOTA-conjugated neolactosylated albumin (LSA), which exhibits 64\% hepatic uptake when labeled with ${ }^{68} \mathrm{Ga}$ [216]. The ${ }^{68} \mathrm{Ga}$ complex of NOTA-hexavalent lactoside, which was developed as a kit for ${ }^{68} \mathrm{Ga}$, shows $20 \%$ hepatic uptake and primary excretion through the kidneys [217]. However, similarly to serum albumin scintigraphy, imaging of biliary structures cannot be performed with these tracers, as their biliary excretion is limited [216].

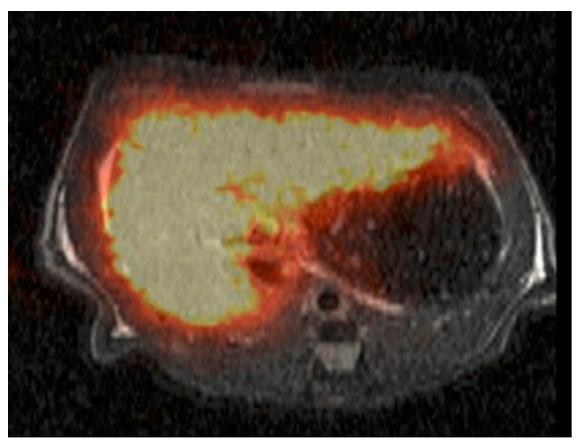

Figure 7. Accumulation of ${ }^{68}$ Ga-NOTA-GSA in rat liver $30 \mathrm{~min}$ p.i. [215].

Direct translation of structures from liver-specific MRI CA into PET tracers, by preparing ${ }^{68}$ Ga-EOB-DTPA, has proved unsuccessful due to the fact of tracer instability and rapid demetallation in vitro, providing, again, evidence that DTPA complexes of ${ }^{68} \mathrm{Ga}$ are of limited applicability [218]. A new class of lipophilic ligands for ${ }^{68} \mathrm{Ga}$ include alkoxysalicyl-substituted DAZA (1,4-diazepane-6-amine) [219], an azacycle that has been established over the lst years as a basis for several ${ }^{68} \mathrm{Ga}$ chelators [220,221]. The novel ${ }^{68} \mathrm{Ga}-\mathrm{DAZA}$ species present a hepatic uptake up to $27 \%$, as well as biliary excretion behavior into the duodenum in ovo, comparably to ${ }^{99 \mathrm{~m}}$ Tc-EHIDA (Figure 8) [219].

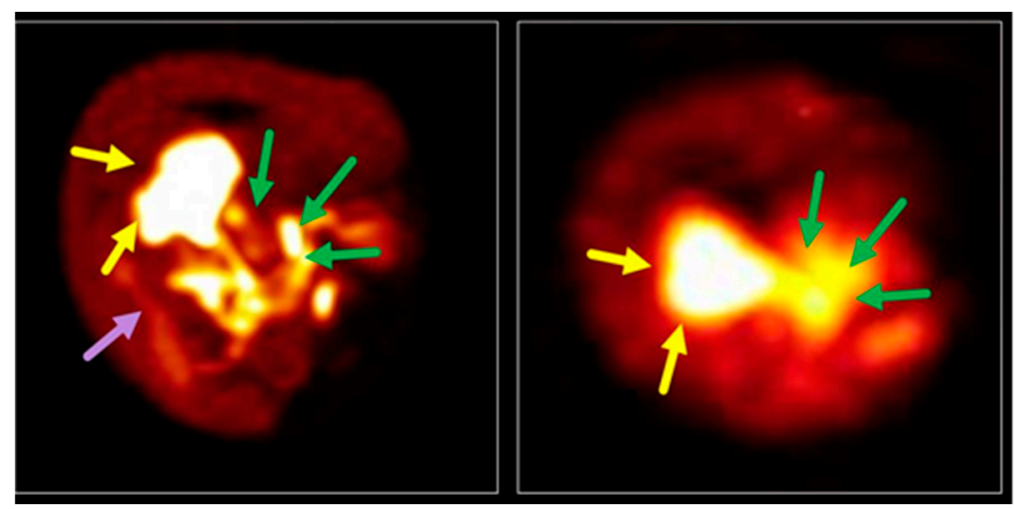

Figure 8. Liver accumulation (yellow arrows) and biliary excretion into the duodenum (green arrows) of ${ }^{68} \mathrm{Ga}$-TEtOHB-DAZA (left) compared to ${ }^{99 \mathrm{~m}} \mathrm{Tc}$-EHIDA (right) in an in ovo model. ${ }^{68} \mathrm{Ga}$-TEtOHB-DAZA also shows slight accumulation in the kidneys (purple arrow) [219]. 
Natural liver-targeting structures like bile acids and hepatic transporter substrates labeled with ${ }^{18} \mathrm{~F}[222,223]$ and ${ }^{11} \mathrm{C}[224,225]$ often exhibit specific hepatic uptake and efflux. Labeling of chelator-conjugated bile acids with ${ }^{64} \mathrm{Cu}$ has been reported in 2015 [226]. Chelator-free ${ }^{64} \mathrm{Cu}$-chloride can be used to identify HCC due to changes in copper metabolism of tumor tissue [227].

Comparably to the preparation of liposomes encapsulating Gd-DTPA, ${ }^{67} \mathrm{Ga}$-deferoxamin trapped in liposomes also accumulates in the RES of mice liver [228]. Furthermore, rat experiments have shown that ${ }^{68} \mathrm{Ga}$-oxine dispersed in lipiodol is also mainly retained in the liver, although there is some leakage of free ${ }^{68} \mathrm{Ga}$ from the lipiodol [3].

\section{Conclusions}

\subsection{Liver-Targeting Metal Complexes-Influence of Ligand and Metal}

A broad spectrum of cholescintigraphic radiopharmaceuticals for scintigraphy and SPECT has been developed in the last decades, including radioiodinated substrates (like ${ }^{131}$ I-labeled rose Bengal) and, in addition to ${ }^{99 \mathrm{~m}} \mathrm{Tc}$ complexes, some metal complexes based on less conventional radiometals like ${ }^{97} \mathrm{Ru}[135,229]$. Development of liver-specific MRI CA has focused primarily on Gd complexes. Several strategies in the design of the complexes can be employed to specifically target the liver:

- Use of glycoprotein conjugates, e.g., galactosyl albumin (NGA, GSA) or galactosylated copolymers, to achieve active uptake into the hepatocytes via targeting of AGPR;

- Generation of small lipophilic, preferably anionic complexes like Gd-EOB-DTPA, ${ }^{99 \mathrm{~m}} \mathrm{Tc}-\mathrm{IDAs}$, ${ }^{99} \mathrm{~m}$ Tc-PMT, or ${ }^{68} \mathrm{Ga}$-BP-IDA [208], or use of derivatives of natural liver targeting substrates like bile acids [223] and bromosulfophthalein [208], to achieve active uptake into the hepatocytes via transporters like OATP;

- $\quad$ Active uptake into the Kupffer cells of the RES via phagocytosis, e.g., using nanoparticles like iron hydroxides or crystalline coated silica, colloids (for example ${ }^{99 \mathrm{~m}} \mathrm{Tc}$-sulfur colloid, ${ }^{99 \mathrm{~m}} \mathrm{Tc}$ albumin colloid) or liposomes;

- Indirect-targeting mechanisms, e.g., Mn(II) uptake into the hepatocytes following in vivo demetallation of Mn-DPDP.

Extensive studies have revealed the dependency between lipophilicity, aromatic substitution pattern, and charge with respect to hepatic uptake, hepatocellular transit time, and biliary excretion rates for Gd-chelates [47] and ${ }^{99} \mathrm{~m}$ Tc-IDA complexes $[135,139,143,161]$. As a general rule, the combination of lipophilic moieties (e.g., aromatic systems or steroid structures) and a negative charge (e.g., provided by a carboxylate) promotes the hepatic uptake $[47,135]$, although several neutral complexes are also taken up by the hepatocytes $[43,46,219]$.

Extent and rate of biliary excretion of any complex strongly depend on liver uptake mechanism, metabolism, and efflux mechanism from the hepatocytes, influencing the possibility to diagnose biliary diseases. In general, RES-targeting substances show little biliary excretion, resulting in prolonged liver accumulation. Also, some pharmaceuticals like the glycoprotein conjugates do not exhibit biliary excretion $[140,169]$. In general, a molecular weight $>5000$ Da represents the upper limit for biliary excretion [135]. Once excreted via the bile, reabsorption from the intestinal tract and enterohepatic circulation must also be considered [135]. Renal excretion represents a competitive way to hepatobiliary excretion, particularly in cases of reduced liver function or bile obstruction. However, renal excretion plays a minor role in the application of nanoparticles exceeding the size limit for glomerular filtration [100] or AGPR substrates, which exclusively address liver cells [133]. Hepatobiliary excretion is prominent for molecules with a molecular weight $>300 \mathrm{Da}$, while smaller molecules are usually excreted renally [135].

In general, the central metal ion influences the overall charge and structure of the substrate, thereby influencing the rate of hepatic uptake. It has been shown that the ${ }^{99 \mathrm{~m}} \mathrm{Tc}$ center is essential for the high hepatobiliary excretion of ${ }^{99 \mathrm{~m}} \mathrm{Tc}-\mathrm{HIDA}$ compared to HIDA [230]. The case of Mn-DPDP, 
which is used as a liver-specific CA due to the release of $\mathrm{Mn}$ (II) from the complex in vivo, emphasizes the relevance of the central metal regarding biodistribution and complex stability. In contrast to Mn-DPDP, in the case of ${ }^{68} \mathrm{Ga}$ or ${ }^{99} \mathrm{~m}$ Tc tracers the integrity of the complex is crucial to maintain a high liver specificity, since ${ }^{68} \mathrm{Ga}$ released from the complex behaves similarly to $\mathrm{Fe}(\mathrm{III})$ and is primarily bound by transferrin, resulting in unspecific distribution in the blood pool [206,219], while the release of ${ }^{99 \mathrm{~m}} \mathrm{Tc}$ is likely to result in accumulation in non-targeted organs, for example the thyroid.

Since the metal ions used for different imaging modalities (i.e., Gd(III) and Mn(II) for MRI, ${ }^{99 \mathrm{~m}} \mathrm{Tc}$ for SPECT, and ${ }^{68} \mathrm{Ga}$ for PET) markedly differ in terms of coordination character (e.g., preferred donor number and hardness, metal oxidation states, and charge), liver-targeting ligands have to be specifically designed for each metal ion to create stable metal complexes. For example, IDA is a small, tridendate ligand forming biscomplexes with $\mathrm{Ga}$ (III) [209] and Gd(III) [41], which have been reported to exhibit low stability, while the ${ }^{99 \mathrm{~m}}$ Tc compounds are sufficiently stable [141]. Therefore, adaptation of the chelator is often necessary, e.g., from DTPA-GSA for ${ }^{99 \mathrm{~m}} \mathrm{Tc}$ to NOTA-GSA for ${ }^{68} \mathrm{Ga}$ [215].

Specifically, in the development of MRI CA, it must be noted that the structure of the ligand can heavily influence the relaxation behavior of a Gd-based agent, thereby impacting its applicability and the doses required for sufficient contrast enhancement and image quality. A comprehensive review on this subject was published by Caravan and coworkers, including a detailed discussion of the influence of molecular weight, ligand structure, water exchange rates, rigidity, and other characteristics on the relaxivity of CA [10]. The additional coordination of water molecules to Gd(III) and their influence on relaxation properties have also to be considered, particularly for ligands providing less than nine donors, since Gd(III) prefers a nona-coordination [41]. Herein lies a substantial difference compared to radiopharmaceuticals, since in this case the image quality is determined by the nature and energy of the emission from the metal nuclide, and the coordination sphere does not play any additional influence.

While not extensively presented in this review, particulate metal-based agents for MRI (SPIOs) and metal-based colloids used in SPECT or PET (to a lesser extent), represent an important branch of liver-specific pharmaceuticals of clinical relevance. Radiopharmaceuticals based on non-metal nuclides like ${ }^{18} \mathrm{~F}$ and ${ }^{11} \mathrm{C}$ must also be taken into consideration regarding a future role for PET liver imaging.

\subsection{Medical Application is Determined by Biodistribution and Imaging Technique}

Owing to a much higher spatial resolution, MRI is vastly superior to SPECT in the identification of liver lesions. Therefore, in clinical routine MRI is primarily used for anatomical diagnosis while scintigraphy or SPECT are primarily used for functional diagnostics [34]. Nevertheless, there is a growing interest in using CA enhanced MRI for liver function tests [35].

The different pharmacokinetics of the tracers determine their field of application: As ${ }^{99} \mathrm{~m}$ Tc-IDAs are cleared very rapidly from the blood and subsequently from the liver, dynamic imaging using SPECT is limited since the temporal resolution is not sufficient for the determination of kinetics and tracer clearance [1]. Therefore, planar dynamic imaging is primarily used in ${ }^{99} \mathrm{~m} \mathrm{Tc}-\mathrm{mebrofenin}$ hepatobiliary scintigraphy [133], and the preferred dynamic parameters in this case are hepatic uptake rate and extraction fraction [1]. On the other hand, static ${ }^{99 \mathrm{~m}} \mathrm{TcGSA}$ is used for the assessment of regional liver function and functional liver volume with static, three-dimensional images using SPECT [35]. ${ }^{99 \mathrm{~m}}$ TcGSA can also be applied for planar dynamic imaging, but due to the limited biliary excretion and slow liver clearance of ${ }^{99 \mathrm{~m}} \mathrm{TcGSA}$, in this case the parameters of choice are blood-clearance rate and hepatic uptake [1,35]. In general, agents with preferential accumulation in the RES allow the assessment of functional liver reserve and lesion identification, however they do not allow the diagnosis of biliary diseases. In MRI, a dual excretion profile of a CA (i.e., biliary and renal) is preferable for patients with compromised hepatobiliary function, because prolonged retention times in the body can be prevented [47]. These and other considerations (e.g., water solubility) are of little importance for SPECT and PET, because the applied doses of radiopharmaceuticals are low, allowing the application of tracers excreted exclusively via the hepatobiliary system. 
In summary, each imaging technique presented here has strengths and limitations, and MRI and nuclear imaging methods remain complementary techniques at this stage of development [6]. MRI with liver-specific CA provides anatomical and functional information based on the blood supply, hepatic uptake and excretion of the agents. SPECT, in turn, provides functional information on hepatic uptake, metabolism, and excretion of a tracer, but the anatomical information remains limited due to low spatial resolution. In SPECT and late-phase MRI, imaging of liver tissue changes (for example metastases) depends on the different hepatic uptake of the agent or tracer, due for example to a reduced expression of transporters in tumoral tissue [41]. Although PET is a powerful diagnostic tool and exhibits superior temporal and spatial resolution compared to SPECT, it has not yet emerged as a dedicated technique for functional liver imaging. Due to the high temporal resolution, PET imaging could additionally provide early-phase vascular imaging, similar to MRI. A unique advantage of PET remains the possibility to obtain quantitative information, which is still limited with SPECT.

Future developments will be guided on one hand by regulatory decisions, most notably the marketing withdrawal (or use limitations) of Gd-based CA, and on the other hand by technical implementations such as increased spatial resolution of new-generation SPECTs and broadened production of ${ }^{68} \mathrm{Ga}$ kits for PET as a feasible alternative to SPECT.

Author Contributions: Conceptualization, M.F.; methodology, J.G.; software, J.G.; validation, W.W. and M.F.; formal analysis, J.G.; investigation, J.G.; resources, M.F.; data curation, J.G.; writing-original draft preparation, J.G.; writing-review and editing, W.W. and M.F.; visualization, J.G. and M.F.; supervision, W.W. and M.F.; project administration, M.F.

Funding: This research received no external funding.

Acknowledgments: Ernesta Palombo-Kinne is gratefully acknowledged for language assistance.

Conflicts of Interest: M. Freesmeyer and J. Greiser hold a patent on liver-specific chelators for radiometal nuclides based on DAZA derivatives. W. Weigand declares no conflicts of interest.

\section{List of Abbreviations}

$\begin{array}{ll}\text { AGP } & \text { asiaglycoprotein } \\ \text { AGPR } & \text { asiaglycoprotein receptor } \\ t \text {-butyl-HBED } & N, N^{\prime} \text {-Bis(5-t-butyl-2-hydroxy3-methylbenzyl)ethylenediamine- } N, N^{\prime} \text {-diacetic acid } \\ \text { BOPTA } & \text { benzyloxymethyl-DTPA } \\ \text { BRIDA } & \text { 3-bromo-2,4,6-trimethyl-IDA (mebrofenin) } \\ \text { BP-IDA } & \text { tetra-bromo-ortho-cresolphthalein IDA } \\ \text { CA } & \text { contrast agent } \\ \text { Cy2DOT } & \text { hexadecahydro-dibenzo[ } b, h][1,4,7,10] \text { tetraazacyclododecine5,8,13,16-tetraacetic acid } \\ \text { DAZA } & 1,4 \text {-diazepane-6-amine } \\ 3,4-D i P-L I C A M & N, N^{\prime} \text {-bis(iso-propyl)- } N, N^{\prime}, N^{\prime \prime} \text {-tris(2,3-dihydroxybenzoyl)-1,5,10-triazadecane } \\ \text { DISIDA } & 2,6 \text {-diisopropyl-IDA } \\ 2,5-B P A-D O 3 A & 10-[2-[(2,5-\text { bis(isopropyl)phenyl)amino]-2-oxoethyl]-DO3A } \\ \text { DO3A } & 1,4,7,10 \text {-tetraazacyclododecane-1,4,7-triacetic acid } \\ \text { DOTA } & 1,4,7-10 \text {-tetraazacyclododecane-1,4,7,10-tetraacetic acid } \\ \text { DTPA } & \text { diethylenetriamine pentaacetic acid } \\ \text { DPDP } & \text { dipyridoxyl-ethylendiamindiacetate-diphosphate } \\ \text { EDTA } & \text { ethylenediamine tetraacetic acid } \\ \text { EHIDA } & 2,6 \text {-diethyl-IDA } \\ \text { EMA } & \text { European Medicines Agency } \\ \text { EOB } & p \text {-ethoxybenzyl } \\ \text { GSA } & \text { galactosyl serum albumin } \\ \text { HCC } & \text { hepatocellular carcinoma } \\ & \end{array}$




$\begin{array}{ll}\text { HIDA } & \text { 2,6-dimethyl-IDA } \\ \text { IOTIDA } & \text { 3-iodo-2,4,6-trimethyl-IDA } \\ \text { ID } & \text { injected dose } \\ \text { IDA } & \text { phenylcarbamoylmethyl iminidoacetic acid } \\ \text { i.v. } & \text { intravenous } \\ \text { MRI } & \text { magnetic resonance imaging } \\ \text { MRP } & \text { multidrug resistance protein } \\ \text { NAFDL } & \text { non-alcoholic fatty liver disease } \\ \text { NGA } & \text { galactosyl-neoglycoalbumin } \\ \text { NOTA } & 1,4,7 \text {-triazacyclononane-1,4,7-triacetic acid } \\ \text { NSF } & \text { nephrogenic systemic fibrosis } \\ \text { NTCP } & \text { Na'/taurocholate co-transporting polypeptide } \\ \text { OATP } & \text { organic anion transporter } \\ \text { PET } & \text { positron emission tomography } \\ \text { p.i. } & \text { post injection } \\ \text { PMT } & N \text {-pyridoxyl-5-methyltryptophane } \\ \text { PIPIDA } & p \text {-isopropyl-IDA } \\ \text { PyC3A } & N \text {-picolyl- } N, N^{\prime}, N^{\prime} \text {-trans-1,2-cyclohexylenediaminetriacetate } \\ \text { PyC3A-3-OBn } & N \text {-[(3-benzyloxy)picolyl]- } N, N^{\prime}, N^{\prime} \text {-trans-1,2-cyclohexylenediaminetriacetate } \\ \text { RNS } & \text { reactive nitrogen species } \\ \text { ROS } & \text { reactive oxygen species } \\ \text { RES } & \text { reticuloendothelial system } \\ \text { SOD } & \text { superoxide dismutase } \\ \text { SPECT } & \text { single photon emission tomography } \\ \text { SPIO } & \text { superparamagnetic iron oxide } \\ \text { TEtOHB-DAZA } & N, 1,4 \text {-Tri(4-ethoxy-2-hydroxybenzyl)-DAZA } \\ \text { USPIO } & \text { Ultra-small superparamagnetic iron oxide } \\ & \\ & \end{array}$

\section{References}

1. Geisel, D.; Hamm, B.; Denecke, T.; Ludemann, L. Imaging-based liver function tests-Past, present and future. Fortschr. Röntgenstr. 2015, 187, 863-871. [CrossRef] [PubMed]

2. Feine, U.; Zum Winkel, K. Nuklearmedizin-Szintigraphische Diagnostik, 2nd ed.; Georg Thieme Verlag: Stuttgart, Germany, 1995.

3. Ghosh, S.; Das, T.; Sarma, H.D.; Banerjee, S. Preparation and preliminary bioevaluation of 68Ga-oxine in lipiodol as a potential liver imaging agent. J. Radioanal. Nucl. Chem. 2016, 311, 263-268. [CrossRef]

4. Blachier, M.; Leleu, H.; Peck-Radosavljevic, M.; Valla, D.-C.; Roudot-Thoraval, F. The burden of liver disease in Europe: A review of available epidemiological data. J. Hepatol. 2013, 58, 593-608. [CrossRef] [PubMed]

5. Alfke, H.; Nocken, F.; Heverhagen, J.T.; Klose, K.J. Molecular radiology. II: Molecular imaging. Fortschr. Röntgenstr. 2001, 173, 391-398. [CrossRef] [PubMed]

6. Meikle, S.R.; Beekman, F.J.; Rose, S.E. Complementary molecular imaging technologies: High resolution SPECT, PET and MRI. Drug Discov. Today Technol. 2006, 3, 187-194. [CrossRef]

7. Rodriguez, A.O. Principles of magnetic resonance imaging. Rev. Mex. Fis. 2004, 50, 272-286.

8. Rogosnitzky, M.; Branch, S. Gadolinium-based contrast agent toxicity: A review of known and proposed mechanisms. BioMetals 2016, 29, 365-376. [CrossRef]

9. Fischbach, F.; Fischbach, K. MRT der Leber-Diagnostik, Differenzialdiagnose, Therapieansätze; Georg Thieme Verlag: Stuttgart, Germany, 2017.

10. Caravan, P.; Ellison, J.J.; McMurry, T.J.; Lauffer, R.B. Gadolinium(III) chelates as MRI contrast agents: Structure, dynamics, and applications. Chem. Rev. 1999, 99, 2293-2352. [CrossRef]

11. Donato, H.; Candelaria, I.; Caseiro-Alves, F.; Franca, M. Liver MRI: From basic protocol to advanced techniques. Eur. J. Radiol. 2017, 93, 30-39. [CrossRef]

12. Bui, T.; Stevenson, J.; Hoekman, J.; Zhang, S.; Maravilla, K.; Ho, R.J.Y. Novel Gd nanoparticles enhance vascular contrast for high-resolution magnetic resonance imaging. PLoS ONE 2010, 5. [CrossRef] 
13. Bonnet, C.S.; Toth, E. MRI Contrast Agents. In Ligand Design in Medicinal Inorganic Chemistry, 1st ed.; Storr, T., Ed.; John Wiley \& Sons Ltd.: Hoboken, NJ, USA, 2014; pp. 321-354.

14. Ba-Ssalamah, A.; Happel, B.; Kettenbach, J.; Dirisamer, A.; Wrba, F.; Längle, F.; Schima, W. MRT der Leber. Der Radiologe 2004, 44, 1170-1184. [CrossRef] [PubMed]

15. Levin, C.S. Primer on molecular imaging technology. Eur. J. Nucl. Med. Mol. Imaging 2005, 32, 325-345. [CrossRef] [PubMed]

16. Dill, T. Contraindications to magnetic resonance imaging: Non-invasive imaging. Heart 2008, 94, 943-948. [CrossRef] [PubMed]

17. Van Beers, B.E.; Pastor, C.M.; Hussain, H.K. Primovist, Eovist-What to expect. J. Hepatol. 2012, 57, 421-429. [CrossRef] [PubMed]

18. Clément, O.; Siauve, N.; Lewin, M.; de Kerviler, E.; Cuénod, C.-A.; Frija, G. Contrast agents in magnetic resonance imaging of the liver: Present and future. Biomed. Pharmacother. 1998, 52, 51-58. [CrossRef]

19. El-Gazzar, M.F.; Kohla, M.A.S.; El-Sakhawy, M.M.; Husseiny, M.M.; Yousef, R.R.H.; El-Shorbagy, S.H. Use of gadobenate dimeglumine dynamic MRI for detection of early hepatocellular carcinoma in atypical hepatic focal lesions. Hepatoma Res. 2017, 3, 123-128. [CrossRef]

20. Thian, Y.L.; Riddell, A.M.; Koh, D.-M. Liver-specific agents for contrast-enhanced MRI: Role in oncological imaging. Cancer Imaging 2013, 13, 567-579. [CrossRef] [PubMed]

21. Ba-Ssalamah, A.; Wibmer, A.; Fragner, R.; Hodge, J.C.; Herold, C.J.; Bastati, N.; Trauner, M.; Bashir, M.R.; Van Beers, B.E. Hepatic gadoxetic acid uptake as a measure of diffuse liver disease: Where are we? J. Magn. Reason. Imaging 2017, 45, 646-659. [CrossRef]

22. Leonhardt, M.; Keiser, M.; Oswald, S.; Kühn, J.; Jia, J.; Grube, M.; Kroemer, H.; Siegmund, W.; Weitschies, W. Hepatic uptake of the magnetic resonance imaging contrast agent Gd-Eob-dtpa: Role of human organic anion transporters. Drug Metab. Dispos. 2010, 38, 1024-1028. [CrossRef]

23. Frydrychowicz, A.; Lubner, M.G.; Brown, J.J.; Merkle, E.M.; Nagle, S.K.; Rofsky, N.M.; Reeder, S.B. Hepatobiliary MR imaging with gadolinium-based contrast agents. J. Magn. Reason. Imaging 2012, 35, 492-511. [CrossRef]

24. Schima, W.; Petersein, J.; Hahn, P.F.; Harisinghani, M.; Halpern, E.; Saini, S. Contrast-enhanced MR imaging of the liver: Comparison between Gd-bopta and mangafodipir. J. Magn. Reason. Imaging 1997, 7, 130-135. [CrossRef] [PubMed]

25. Bae, K.E.; Kim, S.Y.; Lee, S.S.; Kim, K.W.; Won, H.J.; Shin, Y.M.; Kim, P.N.; Lee, M.-G. Assessment of hepatic function with Gd-EOB-DTPA-enhanced hepatic MRI. Dig. Dis. 2012, 30, 617-622. [CrossRef] [PubMed]

26. Grazioli, L.; Bondioni, M.P.; Faccioli, N.; Gambarini, S.; Tinti, R.; Schneider, G.; Kirchin, M. Solid focal liver lesions: Dynamic and late enhancement patterns with the dual phase contrast agent gadobenate dimeglumine. J. Gastrointest. Cancer 2010, 41, 221-232. [CrossRef] [PubMed]

27. Turkbey, B.; Akpinar, E.; Balli, O.; Tirnaksiz, B.; Akata, D.; Akhan, O.; Karcaaltincaba, M. Clinical applications of gadobenate dimeglumine-enhanced magnetic resonance cholangiography: An expanded pictorial review. Jpn. J. Radiol. 2011, 29, 3-10. [CrossRef] [PubMed]

28. Aime, S.; Caravan, P. Biodistribution of gadolinium-based contrast agents, including gadolinium deposition. J. Magn. Reson. Imaging 2009, 30, 1259-1267. [CrossRef] [PubMed]

29. Roberts, L.R.; Heimbach, J.K.; Sirlin, C.B.; Zaiem, F.; Almasri, J.; Prokop, L.J.; Murad, M.H.; Mohammed, K. Imaging for the diagnosis of hepatocellular carcinoma: A systematic review and meta-analysis. Hepatology 2018, 67, 401-421. [CrossRef]

30. Jeong, W.K.; Kim, Y.K.; Song, K.D.; Choi, D.; Lim, H.K. The MR imaging diagnosis of liver diseases using gadoxetic acid: Emphasis on hepatobiliary phase. Clin. Mol. Hepatol. 2013, 19, 360-366. [CrossRef] [PubMed]

31. Duncan,J.K.; Ma, N.; Vreugdenburg, T.D.; Cameron, A.L.; Maddern, G.; Maddern, G. Gadoxetic acid-enhanced MRI for the characterization of hepatocellular carcinoma: A systematic review and meta-analysis. J. Magn. Reson. Imaging 2017, 45, 281-290. [CrossRef]

32. Gotra, A.; Vu, K.-N.; Kauffmann, C.; Tang, A.; Gotra, A.; Gallix, B.; Sivakumaran, L.; Sivakumaran, L.; Kadoury, S.; Tang, A.; et al. Liver segmentation: Indications, techniques and future directions. Insights Imaging 2017, 8, 377-392. [CrossRef]

33. Palmucci, S.; Roccasalva, F.; Piccoli, M.; Fuccio, S.G.; Foti, P.V.; Milone, P.; Ragozzino, A.; Ettorre, G.C. Contrast-enhanced magnetic resonance cholangiography: Practical tips and clinical indications for biliary disease management. Gastroenterol. Res. Pract. 2017. [CrossRef] 
34. Rassam, F.; Cieslak, K.P.; van Gulik, T.M.; Zhang, T.; van Vliet, L.J.; Vos, F.M.; Lavini, C.; Stoker, J.; Bennink, R.J.; Runge, J.H.; et al. Comparison between dynamic gadoxetate-enhanced MRI and (99m)Tc-mebrofenin hepatobiliary scintigraphy with SPECT for quantitative assessment of liver function. Eur. Radiol. 2019, 29, 5063-5072. [CrossRef] [PubMed]

35. Cieslak, K.P.; Runge, J.H.; Heger, M.; Stoker, J.; Bennink, R.J.; van Gulik, T.M. New perspectives in the assessment of future remnant liver. Dig. Surg. 2014, 31, 255-268. [CrossRef] [PubMed]

36. Georgiou, L.; Penny, J.; Nicholls, G.; Woodhouse, N.; Ble, F.-X.; Hubbard, C.P.L.; Naish, J.H. Quantitative assessment of liver function using gadoxetate-enhanced magnetic resonance imaging: Monitoring transporter-mediated processes in healthy volunteers. Investig. Radiol. 2017, 52, 111-119. [CrossRef] [PubMed]

37. You, M.-W.; Kim, H.J.; Lim, H.-S.; Kim, S.Y.; Byun, J.H.; Kim, K.W.; Hwang, D.W.; Lee, Y.-J. Assessment of liver function using pharmacokinetic parameters of Gd-Eob-dtpa: Experimental study in rat hepatectomy model. Contrast Media Mol. Imaging 2018, 6321316/6321311. [CrossRef] [PubMed]

38. Unal, E.; Akata, D.; Karcaaltincaba, M. Liver function assessment by magnetic resonance imaging. Semin. Ultrasound CT MR 2016, 37, 549-560. [CrossRef]

39. Utsunomiya, T.; Shimada, M.; Hanaoka, J.; Kanamoto, M.; Ikemoto, T.; Morine, Y.; Imura, S.; Harada, M. Possible utility of MRI using Gd-EOB-DTPA for estimating liver functional reserve. J. Gastroenterol. 2012, 47, 470-476. [CrossRef] [PubMed]

40. Najafi, A.; Amparo, E.E.; Johnson, R.R., Jr. Gadolinium-labeled pharmaceuticals as potential MRI contrast agents for liver and biliary tract. J. Label. Compd. Radiopharm. 1987, 24, 1131-1141. [CrossRef]

41. Karwowski, B.; Witczak, M.; Mikiciuk-Olasik, E.; Studniarek, M. Gadolinium Gd(III) complexes with derivatives of nitriloacetic acid: Synthesis and biological properties. Acta Pol. Pharm. 2008, 65, 535-541.

42. Markowicz-Piasecka, M.; Sikora, J.; Szymanski, P.; Kozak, O.; Studniarek, M.; Mikiciuk-Olasik, E. Pamam dendrimers as potential carriers of gadolinium complexes of iminodiacetic acid derivatives for magnetic resonance imaging. J. Nanomater. 2015, 394827/394821. [CrossRef]

43. Baek, A.R.; Kim, H.-K.; Park, S.; Lee, G.H.; Kang, H.J.; Jung, J.-C.; Park, J.-S.; Ryeom, H.-K.; Kim, T.-J.; Chang, Y. Gadolinium complex of 1,4,7,10-tetraazacyclododecane-1,4,7-trisacetic acid (DO3A)-ethoxybenzyl (EOB) conjugate as a new macrocyclic hepatobiliary mri contrast agent. J. Med. Chem. 2017, 60, 4861-4868. [CrossRef]

44. Harrison, A.; Walker, C.A.; Pereira, K.A.; Parker, D.; Royle, L.; Pulukkody, K.; Norman, T.J. Hepato-biliary and renal excretion in mice of charged and neutral gadolinium complexes of cyclic tetra-aza-phosphinic and carboxylic acids. Magn. Reson. Imaging 1993, 11, 761-770. [CrossRef]

45. Runge, V.M.; Wells, J.W.; Williams, N.M. Comparison of gadolinium Cy2DOTA, a new hepatobiliary agent, and gadolinium HP-DO3A, an extracellular agent, in healthy liver and metastatic disease. Investig. Radiol. 1995, 30, 123-130. [CrossRef] [PubMed]

46. Runge, V.M.; Wells, J.W.; Williams, N.M. Evaluation of gadolinium 2,5-BPA-DO3A, a new macrocyclic hepatobiliary chelate, in normal liver and metastatic disease on high field magnetic resonance imaging. Investig. Radiol. 1996, 31, 11-16. [CrossRef] [PubMed]

47. Marinelli, E.R.; Neubeck, R.; Song, B.; Wagler, T.; Ranganathan, R.S.; Sukumaran, K.; Wedeking, P.W.; Nunn, A.; Runge, V.M.; Tweedle, M.F. Synthesis, characterization, and imaging performance of a new class of macrocyclic hepatobiliary MR contrast agents. Investig. Radiol. 2000, 35, 8-24. [CrossRef] [PubMed]

48. Anelli, P.L.; Lattuada, L.; Lorusso, V.; Lux, G.; Morisetti, A.; Morosini, P.; Serleti, M.; Uggeri, F. Conjugates of gadolinium complexes to bile acids as hepatocyte-directed contrast agents for magnetic resonance imaging. J. Med. Chem. 2004, 47, 3629-3641. [CrossRef] [PubMed]

49. Tomaselli, S.; Zanzoni, S.; Ragona, L.; Gianolio, E.; Aime, S.; Assfalg, M.; Molinari, H. Solution structure of the supramolecular adduct between a liver cytosolic bile acid binding protein and a bile acid-based gadolinium(III)-chelate, a potential hepatospecific magnetic resonance imaging contrast agent. J. Med. Chem. 2008, 51, 6782-6792. [CrossRef] [PubMed]

50. Muhler, A.; Platzek, J.; Raduchel, B.; Frenzel, T.; Weinmann, H.J. Characterization of a gadolinium-labeled cholesterol derivative as an organ-specific contrast agent for adrenal MR imaging. J. Magn. Reson. Imaging 1995, 5, 7-10. [CrossRef] [PubMed]

51. Vera, D.R.; Buonocore, M.H.; Wisner, E.R.; Katzberg, R.W.; Stadalnik, R.C. A molecular receptor-binding contrast agent for magnetic resonance imaging of the liver. Acad. Radiol. 1995, 2, 497-506. [CrossRef] 
52. Xiao, Y.; Xue, R.; You, T.; Li, X.; Pei, F.; Wang, X.; Lei, H. Gadolinium-1,4,7,10-tetraazacyclododecane-1,4,7,10tetraacetic acid conjugate of arabinogalactan as a potential liver-targeting magnetic resonance imaging contrast agent. Carbohydr. Res. 2014, 395, 9-14. [CrossRef]

53. Unger, E.; Cardenas, D.; Zerella, A.; Fajardo, L.L.; Tilcock, C. Biodistribution and clearance of liposomal gadolinium-DTPA. Investig. Radiol. 1990, 25, 638-644. [CrossRef]

54. Schwendener, R.A.; Wuethrich, R.; Duewell, S.; Wehrli, E.; Von Schulthess, G.K. A pharmacokinetic and MRI study of unilamellar gadolinium-, manganese-, and iron-dtpa-stearate liposomes as organ-specific contrast agents. Investig. Radiol. 1990, 25, 922-932. [CrossRef] [PubMed]

55. Watcharin, W.; Zeuzem, S.; Piiper, A.; Schmithals, C.; Pleli, T.; Koberle, V.; Korkusuz, H.; Huebner, F.; Vogl, T.J.; Korf, H.W.; et al. Biodegradable human serum albumin nanoparticles as contrast agents for the detection of hepatocellular carcinoma by magnetic resonance imaging. Eur. J. Pharm. Biopharm. 2014, 87, 132-141. [CrossRef] [PubMed]

56. Watcharin, W.; Schmithals, C.; Pleli, T.; Koeberle, V.; Korkusuz, H.; Huebner, F.; Waidmann, O.; Zeuzem, S.; Korf, H.-W.; Terfort, A.; et al. Detection of hepatocellular carcinoma in transgenic mice by Gd-DTPA- and rhodamine 123-conjugated human serum albumin nanoparticles in T1 magnetic resonance imaging. J. Control. Release 2015, 199, 63-71. [CrossRef] [PubMed]

57. Wang, L.; Lin, H.; Ma, L.; Jin, J.; Shen, T.; Wei, R.; Wang, X.; Ai, H.; Chen, Z.; Gao, J. Albumin-based nanoparticles loaded with hydrophobic gadolinium chelates as T1-T2 dual-mode contrast agents for accurate liver tumor imaging. Nanoscale 2017, 9, 4516-4523. [CrossRef] [PubMed]

58. Xue, S.; Yang, H.; Grossniklaus, H.E.; Qiao, J.; Pu, F.; Jiang, J.; Hubbard, K.; Salarian, M.; Yang, J.J.; Hekmatyar, K.; et al. Protein MRI contrast agent with unprecedented metal selectivity and sensitivity for liver cancer imaging. Proc. Natl. Acad. Sci. USA 2015, 112, 6607-6612. [CrossRef] [PubMed]

59. Zhang, B.; Jin, H.; Li, Y.; Chen, B.; Liu, S.; Shi, D. Bioinspired synthesis of gadolinium-based hybrid nanoparticles as MRI blood pool contrast agents with high relaxivity. J. Mater. Chem. 2012, 22, 14494-14501. [CrossRef]

60. Primovist@Full Prescribing Information; Bayer Vital GmbH: Reading, UK, 2017.

61. MultiHance ${ }^{\circledR}$ Full Prescribing Information; Bracco Diagnostics Inc.: Monroe Township, NJ, USA, 2018.

62. Information on Primovist ${ }^{\circledR}$ Brochure; Bayer Vital GmbH.: Leverkusen, Germany, 2014.

63. Endrikat, J.; Breuer, J.; Endrikat, J.; Kim, S.Y.; Sakaguchi, T.; Dohanish, S. Safety of gadoxetate disodium: Results from six clinical phase IV studies in 8194 patients. Acta Radiol. 2016, 57, 1326-1333. [CrossRef] [PubMed]

64. Jung, J.-W.; Kang, H.-R.; Kim, M.-H.; Lee, W.; Min, K.-U.; Han, M.-H.; Cho, S.-H. Immediate hypersensitivity reaction to gadolinium-based MR contrast media. Radiology 2012, 264, 414-422. [CrossRef] [PubMed]

65. Granata, V.; Cascella, M.; Fusco, R.; Dell'Aprovitola, N.; Catalano, O.; Filice, S.; Schiavone, V.; Izzo, F.; Cuomo, A.; Petrillo, A. Immediate adverse reactions to gadolinium-based MR contrast media: A retrospective analysis on 10,608 examinations. BioMed Res. Int. 2016, 3918292. [CrossRef] [PubMed]

66. Neeley, C.; Moritz, M.; Brown, J.J.; Zhou, Y. Acute side effects of three commonly used gadolinium contrast agents in the paediatric population. Br. J. Radiol. 2016, 89, 20160027. [CrossRef] [PubMed]

67. Schneider, G.; Schurholz, H.; Kirchin, M.A.; Bucker, A.; Fries, P. Safety and adverse effects during 24 hours after contrast-enhanced MRI with gadobenate dimeglumine (multihance) in children. Pediatr. Radiol. 2013, 43, 202-211. [CrossRef] [PubMed]

68. Todd, D.J.; Todd, D.J.; Kay, J. Gadolinium-induced fibrosis. Annu. Rev. Med. 2016, 67, 273-291. [CrossRef] [PubMed]

69. Beam, A.S.; Moore, K.G.; Gillis, S.N.; Ford, K.F.; Gray, T.; Steinwinder, A.H.; Graham, A. GbCAs and risk for nephrogenic systemic fibrosis: A literature review. Radiol. Technol. 2017, 88, 583-589. [PubMed]

70. Penfield, J.G.; Reilly, R.F., Jr. What nephrologists need to know about gadolinium. Nat. Clin. Pract. Nephrol. 2007, 3, 654-668. [CrossRef] [PubMed]

71. Perez-Rodriguez, J.; Lai, S.; Ehst, B.D.; Fine, D.M.; Bluemke, D.A. Nephrogenic systemic fibrosis: Incidence, associations, and effect of risk factor assessment-report of 33 cases. Radiology 2009, 250, 371-377. [CrossRef] [PubMed]

72. Grobner, T. Gadolinium-A specific trigger for the development of nephrogenic fibrosing dermopathy and nephrogenic systemic fibrosis? Nephrol. Dial. Transplant. 2006, 21, 1104-1108. [CrossRef] [PubMed] 
73. Ramalho, J.; Semelka, R.C.; Ramalho, M.; Nunes, R.H.; Al Obaidy, M.; Castillo, M. Gadolinium-based contrast agent accumulation and toxicity: An update. Am. J. Neuroradiol. 2016, 37, 1192-1198. [CrossRef]

74. Olchowy, C.; Cebulski, K.; Lasecki, M.; Chaber, R.; Olchowy, A.; Kalwak, K.; Zaleska-Dorobisz, U. The presence of the gadolinium-based contrast agent depositions in the brain and symptoms of gadolinium neurotoxicity-A systematic review. PLoS ONE 2017, 12, e0171704. [CrossRef]

75. Kanda, T.; Fukusato, T.; Matsuda, M.; Toyoda, K.; Oba, H.; Kotoku, J.i.; Haruyama, T.; Kitajima, K.; Furui, S. Gadolinium-based contrast agent accumulates in the brain even in subjects without severe renal dysfunction: Evaluation of autopsy brain specimens with inductively coupled plasma mass spectroscopy. Radiology 2015, 276, 228-232. [CrossRef]

76. McDonald, R.J.; McDonald, J.S.; Kallmes, D.F.; Jentoft, M.E.; Paolini, M.A.; Murray, D.L.; Williamson, E.E.; Eckel, L.J. Gadolinium deposition in human brain tissues after contrast-enhanced MR imaging in adult patients without intracranial abnormalities. Radiology 2017, 285, 546-554. [CrossRef]

77. Roberts, D.R.; Lindhorst, S.M.; Welsh, C.T.; Maravilla, K.R.; Herring, M.N.; Braun, K.A.; Thiers, B.H.; Davis, W.C. High levels of gadolinium deposition in the skin of a patient with normal renal function. Investig. Radiol. 2016, 51, 280-289. [CrossRef]

78. White, G.W.; Gibby, W.A.; Tweedle, M.F. Comparison of Gd(DTPA-BMA) (Omniscan) versus Gd(HP-DO3A) (Prohance) relative to gadolinium retention in human bone tissue by inductively coupled plasma mass spectroscopy. Investig. Radiol. 2006, 41, 272-278. [CrossRef] [PubMed]

79. Chehabeddine, L.; Al, S.T.; Baalbaki, M.; Saleh, E.; Khoury, S.J.; Hannoun, S.; Khoury, S.J.; Hannoun, S. Cumulative administrations of gadolinium-based contrast agents: Risks of accumulation and toxicity of linear vs macrocyclic agents. Crit. Rev. Toxicol. 2019, 1-18. [CrossRef] [PubMed]

80. Frenzel, T.; Apte, C.; Jost, G.; Schoeckel, L.; Lohrke, J.; Pietsch, H. Quantification and assessment of the chemical form of residual gadolinium in the brain after repeated administration of gadolinium-based contrast agents: Comparative study in rats. Investig. Radiol. 2017, 52, 396-404. [CrossRef] [PubMed]

81. Prybylski, J.P.; Semelka, R.C.; Jay, M. The stability of gadolinium-based contrast agents in human serum: A reanalysis of literature data and association with clinical outcomes. Magn. Reson. Imaging 2017, 38, 145-151. [CrossRef] [PubMed]

82. Stojanov, D.A.; Vojinovic, S.; Benedeto-Stojanov, D.; Ljubisavljevic, S.; Stojanov, D.A.; Aracki-Trenkic, A.; Vojinovic, S.; Ljubisavljevic, S. Increasing signal intensity within the dentate nucleus and globus pallidus on unenhanced $\mathrm{T} 1 \mathrm{w}$ magnetic resonance images in patients with relapsing-remitting multiple sclerosis: Correlation with cumulative dose of a macrocyclic gadolinium-based contrast agent, gadobutrol. Eur. Radiol. 2016, 26, 807-815. [PubMed]

83. Gianolio, E.; Bardini, P.; Arena, F.; Stefania, R.; Di, G.E.; Iani, R.; Aime, S. Gadolinium retention in the rat brain: Assessment of the amounts of insoluble gadolinium-containing species and intact gadolinium complexes after repeated administration of gadolinium-based contrast agents. Radiology 2017, 285, 839-849. [CrossRef]

84. European Medicines Agency. EMA's Final Opinion Confirms Restrictions on Use of Linear Gadolinium Agents in Body Scans; EMA/457616/2017; European Medicines Agency: Amsterdam, The Netherlands, 2017.

85. Marti-Bonmati, L.; Marti-Bonmati, E. Retention of gadolinium compounds used in magnetic resonance imaging: A critical review and the recommendations of regulatory agencies. Radiologia 2017, 59, 469-477. [CrossRef]

86. Rocklage, S.M.; Cacheris, W.P.; Quay, S.C.; Ekkehardt Hahn, F.; Raymond, K.N. Manganese(II) $N, N^{\prime}$-Dipyridoxylethylenediamine- $N, N^{\prime}$-diacetate 5,5'-Bis(phosphate). Synthesis and Characterization of a Paramagnetic Chelate for Magnetic Resonance Imaging Enhancement. Inorg. Chem. 1989, 28, 477-485. [CrossRef]

87. Cloyd, R.A.; Koren, S.A.; Abisambra, J.F.; Cloyd, R.A.; Cloyd, R.A.; Koren, S.A.; Abisambra, J.F.; Koren, S.A.; Abisambra, J.F.; Abisambra, J.F. Manganese-enhanced magnetic resonance imaging: Overview and central nervous system applications with a focus on neurodegeneration. Front. Aging Neurosci. 2018, 10, 403. [CrossRef]

88. Vogl, T.J.; Hamm, B.; Schnell, B.; Eibl-Eibesfeldt, B.; Steiner, S.; Lissner, J. The clinical value of Mn-DPDP: A new paramagnetic hepatobiliary contrast medium for magnetic resonance tomography of the liver. Fortschr. Röntgenstr. 1991, 155, 568-574. [CrossRef] [PubMed] 
89. Federle, M.; Chezmar, J.; Rubin, D.L.; Weinreb, J.; Freeny, P.; Schmiedl, U.P.; Brown, J.J.; Borrello, J.A.; Lee, J.K.; Semelka, R.C.; et al. Efficacy and safety of mangafodipir trisodium (MnDPDP) injection for hepatic mri in adults: Results of the U.S. Multicenter phase III clinical trials. Efficacy of early imaging. J. Magn. Reson. Imaging 2000, 12, 689-701. [CrossRef]

90. Reimer, P.; Schneider, G.; Schima, W. Hepatobiliary contrast agents for contrast-enhanced MRI of the liver: Properties, clinical development and applications. Eur. Radiol. 2004, 14, 559-578. [CrossRef] [PubMed]

91. Rummeny, E.J.; Torres, C.G.; Kurdziel, J.C.; Nilsen, G.; Op de Beeck, B.; Lundby, B. MnDPDP for MR imaging of the liver. Results of an independent image evaluation of the european phase III studies. Acta Radiol. 1997, 38, 638-642. [PubMed]

92. Kettritz, U.; Schlund, J.F.; Wilbur, K.; Eisenberg, L.B.; Semelka, R.C. Comparison of gadolinium chelates with manganese-DPDP for liver lesion detection and characterization: Preliminary results. Magn. Reson. Imaging 1996, 14, 1185-1190. [CrossRef]

93. Rummeny, E.; Ehrenheim, C.; Gehl, H.B.; Hamm, B.; Laniado, M.; Lodemann, K.P.; Schmiedel, E.; Steudel, A.; Vogl, T.G. Manganese-DPDP as a hepatobiliary contrast agent in the magnetic resonance imaging of liver tumors. Results of clinical phase II trials in germany including 141 patients. Investig. Radiol. 1991, 26. [CrossRef] [PubMed]

94. Sahani, D.V.; O'Malley, M.E.; Bhat, S.; Hahn, P.F.; Saini, S. Contrast-enhanced MRI of the liver with mangafodipir trisodium: Imaging technique and results. J. Comput. Assist. Tomogr. 2002, 26, $216-222$. [CrossRef] [PubMed]

95. Wang, C.; Ahlstrom, H.; Ekholm, S.; Fagertun, H.; Hellstrom, M.; Hemmingsson, A.; Holtas, S.; Isberg, B.; Jonnson, E.; Lonnemark-Magnusson, M.; et al. Diagnostic efficacy of MnDPDP in MR imaging of the liver. A phase III multicentre study. Acta Radiol. 1997, 38, 643-649. [PubMed]

96. Toft, K.G.; Hustvedt, S.O.; Grant, D.; Martinsen, I.; Gordon, P.B.; Friisk, G.A.; Korsmo, A.J.; Skotland, T. Metabolism and pharmacokinetics of Mndpdp in man. Acta Radiol. 1997, 38, 677-689. [CrossRef] [PubMed]

97. Chabanova, E.; Logager, V.B.; Moller, J.M.; Thomsen, H.S. Manganese based MR contrast agents: Formulation and clinical applications. Open Drug Saf. J. 2011, 2, 29-38. [CrossRef]

98. Misselwitz, B.; Muehler, A.; Weinmann, H.-J. A toxicologic risk for using manganese complexes? A literature survey of existing data through several medical specialties. Investig. Radiol. 1995, 30, 611-620. [CrossRef] [PubMed]

99. Gallez, B.; Bacic, G.; Swartz, H.M. Evidence for the dissociation of the hepatobiliary MRI contrast agent Mn-DPDP. Magn. Reson. Med. 1996, 35, 14-19. [CrossRef] [PubMed]

100. Pan, D.; Schmieder, A.H.; Wickline, S.A.; Lanza, G.M. Manganese-based MRI contrast agents: Past, present, and future. Tetrahedron 2011, 67, 8431-8444. [CrossRef] [PubMed]

101. Lim, K.O.; Stark, D.D.; Leese, P.T.; Pfefferbaum, A.; Rocklage, S.M.; Quay, S.C. Hepatobiliary MR imaging: First human experience with MnDPDP. Radiology 1991, 178, 79-82. [CrossRef] [PubMed]

102. Crossgrove, J.; Zheng, W. Manganese toxicity upon overexposure. NMR Biomed. 2004, 17, 544-553. [CrossRef]

103. Aicher, K.P.; Laniado, M.; Kopp, A.F.; Gronewaller, E.; Duda, S.H.; Claussen, C.D. Mn-DPDP-enhanced MR imaging of malignant liver lesions: Efficacy and safety in 20 patients. J. Magn. Reson. Imaging 1993, 3, 731-737. [CrossRef] [PubMed]

104. Ali, S.F.; Duhart, H.M.; Newport, G.D.; Lipe, G.W.; Slikker, W., Jr. Manganese-induced reactive oxygen species: Comparison between $\mathrm{Mn}^{+2}$ and $\mathrm{Mn}^{+3}$. Neurodegeneration 1995, 4, 329-334. [CrossRef]

105. Martinez-Finley, E.J.; Gavin, C.E.; Aschner, M.; Gunter, T.E. Manganese neurotoxicity and the role of reactive oxygen species. Free Radic. Biol. Med. 2013, 62, 65-75. [CrossRef]

106. Patel, R.P.; McAndrew, J.; Sellak, H.; White, C.R.; Jo, H.; Freeman, B.A.; Darley-Usmar, V.M. Biological aspects of reactive nitrogen species. Biochim. Biophys. Acta 1999, 1411, 385-400. [CrossRef]

107. Liu, G.-F.; Filipovic, M.; Heinemann, F.W.; Ivanovic-Burmazovic, I. Seven-coordinate iron and manganese complexes with acyclic and rigid pentadentate chelates and their superoxide dismutase activity. Inorg. Chem. 2007, 46, 8825-8835. [CrossRef]

108. Jiang, Y.; Zheng, W. Cardiovascular toxicities upon manganese exposure. Cardiovasc. Toxicol. 2005, 5, 345-354. [CrossRef]

109. Platzek, J.; Mareski, P.; Niedballa, U.; Raduechel, B.; Weinmann, H.-J.; Misselwitz, B. Perfluoroalkyl-Containing Tetraazacyclododecane Metal Complexes Comprising Sugar Residues, Method for Their Preparation and Use as Imaging Agents. Patent Number WO2002014309A1, 21 February 2002. 
110. Larsen, L.E.; Grant, D. General toxicology of MnDPDP. Acta Radiol. 1997, 38, 770-779. [CrossRef]

111. Jynge, P.; Brurok, H.; Asplund, A.; Towart, R.; Refsum, H.; Karlsson, J.O. Cardiovascular safety of MnDPDP and MnCl2. Acta Radiol 1997, 38, 740-749. [CrossRef]

112. O'Neal, S.L.; Zheng, W. Manganese toxicity upon overexposure: A decade in review. Curr. Environ. Health Rep. 2015, 2, 315-328. [CrossRef]

113. Pan, D.; Caruthers, S.D.; Senpan, A.; Schmieder, A.H.; Wickline, S.A.; Lanza, G.M. Revisiting an old friend: Manganese-based MRI contrast agents. Wiley Interdiscip. Rev. Nanomed. Nanobiotechnol. 2011, 3, 162-173. [CrossRef]

114. Gale, E.M.; Atanasova, I.P.; Blasi, F.; Ay, I.; Caravan, P. A manganese alternative to gadolinium for mri contrast. J. Am. Chem. Soc. 2015, 137, 15548-15557. [CrossRef]

115. Gale, E.M.; Wey, H.-Y.; Ramsay, I.; Yen, Y.-F.; Sosnovik, D.E.; Caravan, P. A manganese-based alternative to gadolinium: Contrast-enhanced $\mathrm{mr}$ angiography, excretion, pharmacokinetics, and metabolism. Radiology 2018, 286, 865-872. [CrossRef]

116. Wang, J.; Wang, H.; Ramsay, I.A.; Erstad, D.J.; Fuchs, B.C.; Tanabe, K.K.; Caravan, P.; Gale, E.M. Manganese-based contrast agents for magnetic resonance imaging of liver tumors: Structure-activity relationships and lead candidate evaluation. J. Med. Chem. 2018, 61, 8811-8824. [CrossRef]

117. Botta, M.; Carniato, F.; Esteban-Gomez, D.; Platas-Iglesias, C.; Tei, L. Mn(ii) compounds as an alternative to gd-based mri probes. Future Med. Chem. 2019, 11, 1461-1483. [CrossRef]

118. Islam, M.K.; Kim, S.; Kim, H.-K.; Park, S.; Lee, G.-H.; Kang, H.J.; Jung, J.-C.; Kim, T.-J.; Chang, Y.; Park, J.-S. Manganese complex of ethylenediaminetetraacetic acid (edta)-benzothiazole aniline (bta) conjugate as a potential liver-targeting MRI contrast agent. J. Med. Chem. 2017, 60, 2993-3001. [CrossRef]

119. Zhu, J.; Gale, E.M.; Atanasova, I.; Rietz, T.A.; Caravan, P. Hexameric Mn(II) dendrimer as MRI contrast agent. Chemistry 2014, 20, 14507-14513. [CrossRef]

120. Leander, P.; Golman, K.; Klaveness, J.; Holtz, E.; Olsson, M.; Leunbach, I. MRI contrast media for the liver. Efficacy in conditions of acute biliary obstruction. Investig. Radiol. 1990, 25, 1130-1134. [CrossRef]

121. Nguyen-Lefebvre, A.T.; Horuzsko, A. Kupffer cell metabolism and function. J. Enzymol. Metab. $2015,1$.

122. Lu, J.; Ma, S.; Sun, J.; Xia, C.; Liu, C.; Wang, Z.; Zhao, X.; Gao, F.; Gong, Q.; Song, B.; et al. Manganese ferrite nanoparticle micellar nanocomposites as MRI contrast agent for liver imaging. Biomaterials 2009, 30, $2919-2928$. [CrossRef]

123. Lee, M.-Y.; Choi, D.; Jang, M.-S.; Lee, J. Biocompatible and biodegradable $\mathrm{Fe}^{3+}$-melanoidin chelate as a potentially safe contrast agent for liver MRI. Bioconjug. Chem. 2018, 29, 2426-2435. [CrossRef]

124. Rahmim, A. PET vs. SPECT: In the context of ongoing developments. Iran. J. Nucl. Med. 2006, 14, 1-20.

125. Kharissova, O.V.; Mendez-Rojas, M.A.; Kharisov, B.I.; Ortiz Mendez, U.; Elizondo Martinez, P. Metal complexes containing natural and artificial radioactive elements and their applications. Molecules 2014, 19, 10755-10802. [CrossRef]

126. Cutler, C.S.; Hennkens, H.M.; Sisay, N.; Huclier-Markai, S.; Jurisson, S.S. Radiometals for combined imaging and therapy. Chem. Rev. 2013, 113, 858-883. [CrossRef]

127. Bartholoma, M.D.; Louie, A.S.; Valliant, J.F.; Zubieta, J. Technetium and gallium derived radiopharmaceuticals: Comparing and contrasting the chemistry of two important radiometals for the molecular imaging era. Chem. Rev. 2010, 110, 2903-2920. [CrossRef]

128. Loberg, M.D.; Cooper, M.; Harvey, E.; Callery, P.; Faith, W. Development of new radiopharmaceuticals based on n-substitution of iminodiacetic acid. J. Nucl. Med. 1976, 17, 633-638.

129. Büll, U.; Schicha, H.; Biersack, H.-J.; Knapp, W.H.; Reiners, C.; Schober, O. Nuklearmedizin, 3rd ed.; Georg Thieme Verlag: Stuttgart, Germany, 2001.

130. Bennink, R.J.; Dinant, S.; Erdogan, D.; Heijnen, B.H.; Straatsburg, I.H.; van Vliet, A.K.; van Gulik, T.M. Preoperative assessment of postoperative remnant liver function using hepatobiliary scintigraphy. J. Nucl. Med. 2004, 45, 965-971.

131. Krishnamurthy, G.T.; Krishnamurthy, S. Cholescintigraphic measurement of liver function: How is it different from other methods? Eur. J. Nucl. Med. Mol. Imaging 2006, 33, 1103-1106. [CrossRef]

132. Rassam, F.; Olthof, P.B.; van Gulik, T.M.; Richardson, H.; Bennink, R.J. Practical guidelines for the use of technetium-99m mebrofenin hepatobiliary scintigraphy in the quantitative assessment of liver function. Nucl. Med. Commun. 2019, 40, 297-307. [CrossRef] 
133. Hoekstra, L.T.; de Graaf, W.; Nibourg, G.A.A.; Heger, M.; Bennink, R.J.; Stieger, B.; van Gulik, T.M. Physiological and biochemical basis of clinical liver function tests: A review. Ann. Surg. 2013, 257, 27-36. [CrossRef]

134. De Graaf, W.; Hausler, S.; Heger, M.; van Ginhoven, T.M.; van Cappellen, G.; Bennink, R.J.; Kullak-Ublick, G.A.; Hesselmann, R.; van Gulik, T.M.; Stieger, B. Transporters involved in the hepatic uptake of (99m)Tc-mebrofenin and indocyanine green. J. Hepatol. 2011, 54, 738-745. [CrossRef]

135. Chervu, L.R.; Nunn, A.D.; Loberg, M.D. Radiopharmaceuticals for hepatobiliary imaging. Semin. Nucl. Med. 1982, 12, 5-17. [CrossRef]

136. Rassam, F.; Olthof, P.B.; van Gulik, T.M.; Bennink, R.J. Current modalities for the assessment of future remnant liver function. Visc. Med. 2017, 33, 442-448. [CrossRef]

137. Gupta, M.; Choudhury, P.S.; Singh, S.; Hazarika, D. Liver functional volumetry by Tc-99m mebrofenin hepatobiliary scintigraphy before major liver resection: A game changer. Indian J. Nucl. Med. 2018, 33, 277-283. [CrossRef]

138. Krishnamurthy, G.T.; Turner, F.E. Pharmacokinetics and clinical application of technetium $99 \mathrm{~m}-$ labeled hepatobiliary agents. Semin. Nucl. Med. 1990, 20, 130-149. [CrossRef]

139. Nunn, A.D.; Loberg, M.D.; Conley, R.A. A structure-distribution-relationship approach leading to the development of Tc-99m mebrofenin: An improved cholescintigraphic agent. J. Nucl. Med. 1983, 24, 423-430.

140. de Graaf, W.; Bennink, R.J.; Vetelainen, R.; van Gulik, T.M. Nuclear imaging techniques for the assessment of hepatic function in liver surgery and transplantation. J. Nucl. Med. 2010, 51, 742-752. [CrossRef]

141. EHIDA ${ }^{\circledR}$ Full Prescribing Information; ROTOP GmbH: Dresden, Germany, 2014.

142. Bridatec ${ }^{\circledR}$ Full Prescribing Information; GE Healthcare Buchler GmbH \& Co. KG: Braunschweig, Germany, 2013.

143. Krishnamurthy, S.; Krishnamurthy, G.T. Technetium-99m-iminodiacetic acid organic anions: Review of biokinetics and clinical application in hepatology. Hepatology 1989, 9, 139-153. [CrossRef]

144. Ghibellini, G.; Leslie, E.M.; Pollack, G.M.; Brouwer, K.L.R. Use of Tc-99m mebrofenin as a clinical probe to assess altered hepatobiliary transport: Integration of in vitro, pharmacokinetic modeling, and simulation studies. Pharm. Res. 2008, 25, 1851-1860. [CrossRef]

145. Choletec ${ }^{\circledR}$ Instruction Leaflet; Bracco Diagnostics Inc.: Monroe Township, NJ, USA, 2014.

146. Fraser, I.A.; Shaffer, P.; Love, J.; Staubus, A.E.; Hinkle, G.; Olsen, J.; Carey, L.C.; Fabri, P.J.; Ellison, E.C. Pharmacokinetic studies of disida disposition. I. Animal studies. Eur. J. Nucl. Med. 1988, 14, 431-435. [CrossRef]

147. Fraser, I.A.; Shaffer, P.; Staubus, A.E.; Tuttle, S.; Carey, L.C.; Ellison, E.C. DISIDA kinetics measure liver function in dogs. Nucl. Med. Commun. 1989, 10, 435-447. [CrossRef]

148. Zmbova, B.; Konstantinovska-Djokic, D.; Kostic, K.; Obradovic, V. Synthesis and quality control of 2,6-diisopropyl IDA and its labelling with technetium-99m. Isotopenpraxis 1987, 23, 278-281.

149. Gambhir, S.S.; Hawkins, R.A.; Huang, S.C.; Hall, T.R.; Busuttil, R.W.; Phelps, M.E. Tracer kinetic modeling approaches for the quantification of hepatic function with technetium-99m DISIDA and scintigraphy. J. Nucl. Med. 1989, 30, 1507-1518.

150. Park, S.H.; Gwon, H.J.; Park, J.S.; Park, K.B. Synthesis and radiochemical labeling of N-(2,6-diisopropylacetanilido)-iminodiacetic acid and its analogues under microwave irradiation: A hepatobiliary imaging agent. QSAR Comb. Sci. 2004, 23, 868-874. [CrossRef]

151. Hong, Y.-D.; Jang, B.-S.; Choi, S.-M.; Park, W.-W.; Park, K.-B.; Choi, S.-J. Preparation and in-vivo evaluation of 99mTc-IOTIDA for cholescintigraphy. Appl. Radiat. Isot. 2004, 61, 1273-1278. [CrossRef]

152. Chauhan, U.P.S.; Mishra, P.; Chander, J. Technetium-99m-diethylmonoiodo-IDA: A radiopharmaceutical for hepatobiliary scintigraphy. Appl. Radiat. Isot. 1993, 44, 843-848. [CrossRef]

153. Horiuchi, K.; Saji, H.; Arano, Y.; Yokoyama, A. Ligandin binding phthalein complexone complex of technetium for hepatic function studies. Eur. J. Nucl. Med. 1990, 16, 137-142. [CrossRef]

154. Kato-Azuma, M. Technetium-99m(tin)-N-pyridoxylaminates: A new series of hepatobiliary imaging agents. J. Nucl. Med. 1982, 23, 517-524.

155. Kato-Azuma, M. Lipophilic derivatives of $99 \mathrm{mTc}(\mathrm{Sn})$ pyridoxylidenephenylalanine: A structure distribution relationship (sdr) study on technetium-99m complexes. Int. J. Appl. Radiat. Isot. 1982, 33, 937-944. [CrossRef] 
156. Oyamada, H.; Yamazaki, S.; Makuuchi, M.; Hasegawa, H. Clinical significance of technetium-99m-N-pyridoxyl-5-methyltryptophan (technetium-99m-PMT) in the diagnosis of intrahepatic masses. Radioisotopes 1989, 38, 244-251. [CrossRef]

157. Kanazawa, A.; Kubo, S.; Tanaka, H.; Takemura, S.; Yamazaki, K.; Hirohashi, K.; Shiomi, S. Bile leakage after living donor liver transplantation demonstrated with hepatobiliary scan using 99mTcPMT. Ann. Nucl. Med. 2003, 17, 507-509. [CrossRef]

158. Kobayashi, M. Transport mechanisms of hepatic uptake and bile excretion in clinical hepatobiliary scintigraphy with ${ }^{99 m}$ Tc-N-pyridoxyl-5-methyltryptophan. Nucl. Med. Biol. 2014, 338. [CrossRef]

159. Chen, M.; Will, Y. Methods in Pharmacology and Toxicology: Drug-Induced Liver Toxicity; Springer: New York, NY, USA, 2018.

160. Ono, Y.; Yamamoto, Y.; Itoh, S.; Arai, H.; Aga, F.; Nishiyama, Y. SPECT/CT imaging in 99mTc-PMT hepatobiliary scintigraphy to detect bone metastases from hepatocellular carcinoma. Clin. Nucl. Med. 2012, 37, 1011-1012. [CrossRef]

161. Kim, J.-H.; Choi, S.-J.; Hong, Y.-D. Characterization of ${ }^{99} \mathrm{~m} \mathrm{Tc}(\mathrm{CO})_{3}$-iminodiacetic acid (IDA) and its comparison with ${ }^{99 \mathrm{~m}} \mathrm{Tc}-(\mathrm{IDA}) 2$ using compounds for hepatobiliary scintigraphy. J. Radioanal. Nucl. Chem. 2012, 292, 203-209. [CrossRef]

162. Huang, L.; Zhu, H.; Xu, X.; Zhang, C.; Shen, Y.-M. Synthesis and characterization of organometallic rhenium(I) and technetium(I) bile acid complexes. J. Organomet. Chem. 2009, 694, 3247-3253. [CrossRef]

163. Betebenner, D.A.; Carney, P.L.; Zimmer, A.M.; Kazikiewicz, J.M.; Brucher, E.; Sherry, A.D.; Johnson, D.K. Hepatobiliary delivery of polyaminopolycarboxylate chelates: Synthesis and characterization of a cholic acid conjugate of edta and biodistribution and imaging studies with its indium-111 chelate. Bioconjug. Chem. 1991, 2, 117-123. [CrossRef]

164. Iimuro, Y. ICG clearance test and 99mTc-GSA SPECT/CT fusion images. Visc. Med. 2017, 33, 449-454. [CrossRef]

165. Kokudo, N.; Vera, D.R.; Makuuchi, M. Clinical application of TcGSA. Nucl. Med. Biol. 2003, 845-849. [CrossRef]

166. Stadalnik, R.C.; Vera, D.R. The evolution of $(99 \mathrm{~m})$ Tc-NGA as a clinically useful receptor-binding radiopharmaceutical. Nucl. Med. Biol. 2001, 28, 499-503. [CrossRef]

167. Kotani, K.; Kawabe, J.; Higashiyama, S.; Yoshida, A.; Kawamura, E.; Tamori, A.; Shiomi, S.; Kawada, N. Heterogenous liver uptake of Tc-99m-GSA as quantified through SPECT/CT helps to evaluate the degree of liver fibrosis. Medicine 2018, 97, e11765. [CrossRef]

168. Liu, C.; Guo, Z.; Zhang, P.; Song, M.; Zhao, Z.; Wu, X.; Zhang, X. Kit formulated asialoglycoprotein receptor targeting tracer based on copolymer for liver SPECT imaging. Nucl. Med. Biol. 2014, 41, 587-593. [CrossRef]

169. Yang, W.; Mou, T.; Shao, G.; Wang, F.; Zhang, X.; Liu, B. Copolymer-based hepatocyte asialoglycoprotein receptor targeting agent for spect. J. Nucl. Med. 2011, 52, 978-985. [CrossRef]

170. Zhang, D.; Guo, Z.; Zhang, P.; Li, Y.; Su, X.; You, L.; Gao, M.; Liu, C.; Wu, H.; Zhang, X. Simplified quantification method for in vivo SPECT/CT imaging of asialoglycoprotein receptor with 99mTc-p(VLA-co-VNI) to assess and stage hepatic fibrosis in mice. Sci. Rep. 2016, 6, 25377. [CrossRef]

171. Zhang, P.; Guo, Z.; Zhang, D.; Liu, C.; Chen, G.; Zhuang, R.; Song, M.; Wu, H.; Zhang, X. A novel copolymer-based functional SPECT/MR imaging agent for asialoglycoprotein receptor targeting. Mol. Imaging 2016, 15, 1-9. [CrossRef]

172. Kim, E.-M.; Jeong, H.-J.; Park, I.-K.; Cho, C.-S.; Kim, C.-G.; Bom, H.-S. Hepatocyte-targeted nuclear imaging using 99mTc-galactosylated chitosan: Conjugation, targeting, and biodistribution. J. Nucl. Med. 2004, 46, 141-145.

173. Vera, D.R.; Hall, D.J.; Hoh, C.K.; Gallant, P.; McIntosh, L.M.; Mattrey, R.F. Cy5.5-DTPA-galactosyl-dextran: A fluorescent probe for in vivo measurement of receptor biochemistry. Nucl. Med. Biol. 2005, 32, 687-693. [CrossRef]

174. Arano, Y.; Mukai, T.; Akizawa, H.; Uezono, T.; Motonari, H.; Wakisaka, K.; Kairiyama, C.; Yokoyama, A. Radiolabeled metabolites of proteins play a critical role in radioactivity elimination from the liver. Nucl. Med. Biol. 1995, 22, 555-564. [CrossRef]

175. Lee, R.T.; Wang, M.-H.; Lin, W.-J.; Lee, Y.C. New and more efficient multivalent glyco-ligands for asialoglycoprotein receptor of mammalian hepatocytes. Bioorg. Med. Chem. 2011, 19, 2494-2500. [CrossRef] 
176. Wang, M.-H.; Chien, C.-Y.; Wang, P.-Y.; Yu, H.-M.; Lee, H.-S.; Lin, W.-J. The specificity and accuracy of 111In-hexavalent lactoside in estimating liver reserve and its threshold value for mortality in mice. J. Hepatol. 2015, 63, 370-377. [CrossRef]

177. Wang, M.-H.; Chien, C.-Y.; Yu, H.-M.; Wang, P.-Y.; Lin, W.-J. Use of 111In-hexavalent lactoside for liver reserve estimation in rodents with thioacetamide-induced hepatic fibrosis. Mol. Pharm. 2018, 15, 4417-4425. [CrossRef]

178. Prata, M.I.M.; Santos, A.C.; Neves, M.; Geraldes, C.F.G.C.; de Lima, J.J.P. $153 \mathrm{Sm}^{3+}$ and $111 \mathrm{In}^{3+}$ DTPA derivatives with high hepatic specificity: In vivo and in vitro studies. J. Inorg. Biochem. 2002, 91, 312-319. [CrossRef]

179. Prata, M.I.M.; Santos, A.C.; Bligh, S.W.A.; Chowdhury, A.H.M.S.; Geraldes, C.F.G.C.; De Lima, J.J.P. Characterization of $111 \mathrm{In}^{3+}$ complexes of dtpa amide derivatives: Biodistribution and clearance studied by gamma imaging. Nucl. Med. Biol. 2000, 27, 605-610. [CrossRef]

180. Hasegawa, Y.; Nakano, S.; Ishiguro, S.; Imaoka, S.; Sasaki, Y.; Tanaka, S.; Kasugai, H.; Kojima, J.; Ishigami, S. Comparison of delayed hepatobiliary imaging using 99mTc-Sn-N-pyridoxyl-5-methyltryptophan and 67Ga-citrate imaging for diagnosis of hepatocellular carcinoma. Eur. J. Nucl. Med. 1988, 14, 414-418. [CrossRef]

181. Noujaim, A.A.; Lentle, B.C.; Hill, J.R.; Terner, U.K.; Wong, H. On the role of transferrin in the uptake of gallium by tumor cells. Int. J. Nucl. Med. Biol. 1979, 6, 193-199. [CrossRef]

182. Murahashi, H. Study on the pathway of gallium-67 uptake into cultured tumor cells. Kanagawa Shigaku 1988, 23, 1-14.

183. Ohkubo, Y.; Shibuya, A.; Kohno, H.; Kubodera, A. Involvement of transferrin in the uptake of $67 \mathrm{ga}$ in inflammatory and normal tissues. Int. J. Radiat. Appl. Instrum. B 1989, 16, 337-341. [CrossRef]

184. Levin, J.; Kew, M.C. Gallium-67-citrate scanning in primary cancer of the liver: Diagnostic value in the presence of cirrhosis and relation to alpha-fetoprotein. J. Nucl. Med. 1975, 16, 949-951.

185. Matesan, M.M.; Bowen, S.R.; Chapman, T.R.; Miyaoka, R.S.; Velez, J.W.; Wanner, M.F.; Nyflot, M.J.; Apisarnthanarax, S.; Vesselle, H.J. Assessment of functional liver reserve: Old and new in 99mTc-sulfur colloid scintigraphy. Nucl. Med. Commun. 2017, 38, 577-586. [CrossRef]

186. Geslien, G.E.; Pinsky, S.M.; Poth, R.K.; Johnson, M.C. The sensitivity and specificity of 99mTc-sulfur colloid liver imaging in diffuse hepatocellular disease. Radiology 1976, 118, 115-119. [CrossRef]

187. Bekerman, C.; Gottschalk, A. Diagnostic significance of the relative uptake of liver compared with spleen in technetium-99m-sulfur colloid scintiphotography. J. Nucl. Med. 1971, 12, 237-240.

188. Huet, P.M.; Chartrand, R.; Marleau, D. Extrahepatic uptake of 99mTc-phytate: Its mechanism and significance in chronic liver disease. Gastroenterology 1980, 78, 76-80. [CrossRef]

189. Noronha, O.P.; Sewatkar, A.B. Comparison of three re agents- $99 \mathrm{mTc}$-phytate, $99 \mathrm{mTc}$-sulfur colloid and 99mTc-Sb2S3 colloid in the rodent species. Int. J. Radiat. Appl. Instrum. B 1986, 13, 67-73. [CrossRef]

190. Arzoumanian, A.; Rosenthall, L.; Seto, H. Clinical comparison of 99mTc-labeled preformed phytate colloid and sulfur colloid: Concise communication. J. Nucl. Med. 1977, 18, 118-120.

191. Fernandes, R.S.; Mota, L.G.; Kalbasi, A.; Moghbel, M.; Werner, T.J.; Alavi, A.; Rubello, D.; Cardoso, V.N.; de Barros, A.L.B. $99 \mathrm{mTc}$-phytate as a diagnostic probe for assessing inflammatory reaction in malignant tumors. Nucl. Med. Commun. 2015, 36, 1042-1048. [CrossRef]

192. Haubner, R.; Vera, D.R.; Farshchi-Heydari, S.; Helbok, A.; Rangger, C.; Putzer, D.; Virgolini, I.J. Development of (68)Ga-labelled DTPA galactosyl human serum albumin for liver function imaging. Eur. J. Nucl. Med. Mol. Imaging 2013, 40, 1245-1255. [CrossRef]

193. Phytacis ${ }^{\circledR}$ _Full Prescribing Information; CIS Bio International: Gif-sur-Yvette, France, 2017.

194. Anger, H.O. Scintillation camera. Rev. Sci. Instrum. 1958, 29, 27-33. [CrossRef]

195. Price, T.W.; Greenman, J.; Stasiuk, G.J. Current advances in ligand design for inorganic positron emission tomography tracers 68Ga, 64Cu, 89Zr and 44Sc. Dalton Trans. 2016, 45, 15702-15724. [CrossRef]

196. Rahmim, A.; Zaidi, H. PET versus SPECT: Strengths, limitations and challenges. Nucl. Med. Commun. 2008, 29, 193-207. [CrossRef]

197. Velikyan, I. Continued rapid growth in 68Ga applications: Update 2013 to june 2014. J. Label. Compd. Radiopharm. 2015, 58, 99-121. [CrossRef]

198. Brandt, M.; Cardinale, J.; Aulsebrook, M.L.; Gasser, G.; Mindt, T.L. An overview of PET radiochemistry, part 2: Radiometals. J. Nucl. Med. 2018, 59, 1500-1506. [CrossRef] 
199. Roesch, F. Past, present and future of 68Ge/68Ga generators. Appl. Radiat. Isot. 2013, 76, 24-30. [CrossRef]

200. Velikyan, I. 68Ga-based radiopharmaceuticals: Production and application relationship. Molecules 2015, 20, 12913-12943. [CrossRef]

201. Chakravarty, R.; Chakraborty, S.; Ram, R.; Vatsa, R.; Bhusari, P.; Shukla, J.; Mittal, B.R.; Dash, A. Detailed evaluation of different $68 \mathrm{Ge} / 68 \mathrm{Ga}$ generators: An attempt toward achieving efficient $68 \mathrm{Ga}$ radiopharmacy. J. Label. Compd. Radiopharm. 2016, 59, 87-94. [CrossRef]

202. Fani, M.; Andre, J.P.; Maecke, H.R. 68Ga-PET: A powerful generator-based alternative to cyclotron-based PET radiopharmaceuticals. Contrast Media Mol. Imaging 2008, 3, 67-77. [CrossRef]

203. Buck, A.K.; Stollfuss, J.C.; Stahl, A.; Beer, A.J.; Meisetschlager, G.; Schwaiger, M. Nuclear medical diagnostics for liver tumors. Internist 2007, 48, 26-29.

204. Detry, O.; Govaerts, L.; Deroover, A.; Vandermeulen, M.; Meurisse, N.; Malenga, S.; Bletard, N.; Mbendi, C.; Lamproye, A.; Honore, P.; et al. Prognostic value of 18F-FDG PET/CT in liver transplantation for hepatocarcinoma. World J. Gastroenterol. 2015, 21, 3049-3054. [CrossRef]

205. Cheung, T.T.; Ho, C.L.; Lo, C.M.; Chen, S.; Chan, S.C.; Chok, K.S.H.; Fung, J.Y.; Chan, A.C.Y.; Sharr, W.; Yau, T.; et al. 11C-acetate and 18F-FDG PET/CT for clinical staging and selection of patients with hepatocellular carcinoma for liver transplantation on the basis of milan criteria: Surgeon's perspective. J. Nucl. Med. 2013, 54, 192-200. [CrossRef]

206. Aparici, C.M.; Behr, S.C.; Seo, Y.; Kelley, R.K.; Corvera, C.; Gao, K.T.; Aggarwal, R.; Evans, M.J. Imaging hepatocellular carcinoma with 68Ga-citrate PET: First clinical experience. Mol. Imaging 2017, 16, 1-4. [CrossRef]

207. McInnes, L.E.; Rudd, S.E.; Donnelly, P.S. Copper, gallium and zirconium positron emission tomography imaging agents: The importance of metal ion speciation. Coord. Chem. Rev. 2017, 352, 499-516. [CrossRef]

208. Schuhmacher, J.; Matys, R.; Hauser, H.; Clorius, J.H.; Maier-Borst, W. A Ga-68-labeled tetrabromophthalein (Ga-68 BP-IDA) for positron imaging of hepatobiliary function: Concise communication. J. Nucl. Med. 1983, 24, 593-602.

209. Pfeifer-Leeg, M.; Szabo, G.; Baranyai, Z.; Niksch, T.; Weigand, W.; Freesmeyer, M. Synthesis and characterization of GaIII, YIII, and LuIII complexes with etifenin and analogues. Z. Anorg. Allg. Chem. 2016, 642, 486-491. [CrossRef]

210. Mathias, C.J.; Sun, Y.; Welch, M.J.; Green, M.A.; Thomas, J.A.; Wade, K.R.; Martell, A.E. Targeting radiopharmaceuticals: Comparative biodistribution studies of gallium and indium complexes of multidentate ligands. Nucl. Med. Biol. 1988, 15, 69-81. [CrossRef]

211. Moerlein, S.M.; Welch, M.J. Tricatecholamide analogs of enterobactin as gallium- and indium-binding radiopharmaceuticals. J. Nucl. Med. 1981, 22, 710-719.

212. Schuhmacher, J.; Maier-Borst, W.; Wellman, H.N. Liver and kidney imaging with gallium-68-labeled dihydroxyanthraquinones. J. Nucl. Med. 1980, 21, 983-987.

213. Kumar, B.; Miller, T.R.; Siegel, B.A.; Mathias, C.J.; Markham, J.; Ehrhardt, G.J.; Welch, M.J. Positron tomographic imaging of the liver: 68Ga iron hydroxide colloid. Am. J. Roentgenol. 1981, 136, 685-690. [CrossRef]

214. Vera, D.R. Gallium-labeled deferoxamine-galactosyl-neoglycoalbumin: A radiopharmaceutical for regional measurement of hepatic receptor biochemistry. J. Nucl. Med. 1992, 33, 1160-1166.

215. Haubner, R.; Schmid, A.M.; Maurer, A.; Rangger, C.; Roig, L.G.; Pichler, B.J.; Virgolini, I.J. [68Ga]NOTA-galactosyl human serum albumin: A tracer for liver function imaging with improved stability. Mol. Imaging Biol. 2017, 19, 723-730. [CrossRef]

216. Choi, J.; Jeong, J.M.; Yoo, B.C.; Hong, M.K.; Kim, Y.J.; Lee, Y.-S.; Lee, D.S.; Chung, J.-K. Ga-68-labeled neolactosylated human serum albumin (LSA) for PET imaging of hepatic asialoglycoprotein receptor. Nucl. Med. Biol. 2014, 42, 53-58. [CrossRef]

217. Yu, H.-M.; Chan, C.-H.; Chen, J.-H.; Chien, C.-Y.; Wang, P.-Y.; Juan, W.-C.; Yang, C.-H.; Hsia, H.-T.; Wang, M.-H.; Lin, W.-J. Development of single vial kits for preparation of 68Ga-labelled hexavalent lactoside for PET imaging of asialoglycoprotein receptor. J. Label. Compd. Radiopharm. 2018, 61, 885-894. [CrossRef]

218. Greiser, J.; Niksch, T.; Freesmeyer, M.; Weigand, W. Investigations on the Ga(III) complex of EOB-DTPA and its 68Ga radiolabeled analogue. J. Vis. Exp. 2016. [CrossRef] 
219. Greiser, J.; Kuehnel, C.; Goerls, H.; Weigand, W.; Freesmeyer, M. N,1,4-tri(4-alkoxy-2-hydroxybenzyl)-DAZA: Efficient one-pot synthesis and labelling with $68 \mathrm{Ga}$ for PET liver imaging in ovo. Dalton Trans. 2018, 47, 9000-9007. [CrossRef]

220. Waldron, B.P.; Parker, D.; Burchardt, C.; Yufit, D.S.; Zimny, M.; Roesch, F. Structure and stability of hexadentate complexes of ligands based on aazta for efficient PET labelling with gallium-68. Chem. Commun. 2013, 49, 579-581. [CrossRef]

221. Seemann, J.; Waldron, B.P.; Roesch, F.; Parker, D. Approaching 'kit-type' labelling with 68Ga: The DATA chelators. Chem. Med. Chem. 2015, 10, 1019-1026. [CrossRef]

222. Jia, L.; Jiang, D.; Hu, P.; Li, X.; Shi, H.; Cheng, D.; Zhang, L. Synthesis and evaluation of 18F-labeled bile acid compound: A potential PET imaging agent for FXR-related diseases. Nucl. Med. Biol. 2014, 41, 495-500. [CrossRef]

223. Testa, A.; Dall'Angelo, S.; Mingarelli, M.; Augello, A.; Schweiger, L.; Welch, A.; Elmore, C.S.; Sharma, P.; Zanda, M. Design, synthesis, in vitro characterization and preliminary imaging studies on fluorinated bile acid derivatives as PET tracers to study hepatic transporters. Bioorg. Med. Chem. 2017, 25, 963-976. [CrossRef]

224. Testa, A.; Zanda, M.; Elmore, C.S.; Sharma, P. PET tracers to study clinically relevant hepatic transporters. Mol. Pharm. 2015, 12, 2203-2216. [CrossRef]

225. Langer, O. Use of PET imaging to evaluate transporter-mediated drug-drug interactions. J. Clin. Pharmacol. 2016, 56, S143-CS156. [CrossRef] [PubMed]

226. Chong, H.-S.; Chen, Y.; Kang, C.S.; Sun, X.; Wu, N. Novel 64Cu-radiolabeled bile acid conjugates for targeted PET imaging. Bioorg. Med. Chem. Lett. 2015, 25, 1082-1085. [CrossRef] [PubMed]

227. Wachsmann, J.; Peng, F. Molecular imaging and therapy targeting copper metabolism in hepatocellular carcinoma. World J. Gastroenterol. 2016, 22, 221-231. [CrossRef]

228. Huang, S.K.; Lee, K.D.; Hong, K.; Friend, D.S.; Papahadjopoulos, D. Microscopic localization of sterically-stabilized liposomes in colon carcinoma-bearing mice. Cancer Res. 1992, 52, 5135-5143. [PubMed]

229. Zanzi, I.; Srivastava, S.C.; Meinken, G.E.; Robeson, W.; Mausner, L.F.; Fairchild, R.G.; Margouleff, D.A. New cholescintigraphic agent: Ruthenium-97-DISIDA. Nucl. Med. Biol. 1989, 16, 397-403. [CrossRef]

230. Ryan, J.; Cooper, M.; Loberg, M.; Harvey, E.; Sikorski, S. Technetium-99m-labeled n-(2,6-dimethylphenylcarbamoylmethyl) iminodiacetic acid (Tc-99m HIDA): A new radiopharmaceutical for hepatobiliary imaging studies. J. Nucl. Med. 1977, 18, 997-1004. 